University of Miami Law School

University of Miami School of Law Institutional Repository

2020

In Times of Chaos: Creating Blueprints for Law School Responses to Natural Disasters

Jeffrey Baker

Christine Cerniglia

Davida Finger

Luz Herrera

JoNel Newman

Follow this and additional works at: https://repository.law.miami.edu/fac_articles

Part of the Legal Education Commons, and the Legal Profession Commons 


\title{
In Times of Chaos: Creating Blueprints for Law School Responses to Natural Disasters
}

\author{
Jeffrey R. Baker, Christine E. Cerniglia, Davida Finger, Luz \\ Herrera, and JoNel Newman*
}

TABLE OF CONTENTS

Introduction ...................................................................... 423

I. Assessing Legal Needs and Capacity Post-Disaster................... 425

A. Social Injustice Is Exacerbated by Natural Disasters ........... 425

B. Identifying Legal Needs in Context................................... 428

C. Assessing Clinic Resources and Capacity ........................... 431

II. The Ecosystem of Agencies, Law, and Resources

After a Natural Disaster........................................................... 434

A. Federal Emergency Management Agency ........................... 434

B. State and Local Agencies................................................ 437

C. The American Bar Association and State Bar

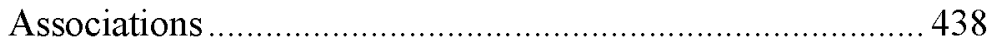

D. Legal Aid .............................................................. 440

E. Pro Bono Lawyers ........................................................... 442

F. Resources Beyond Legal Needs ..................................... 442

III. Tested Models for Law School and Legal Clinic

Responses to Natural Disasters

A. Law Schools and Legal Clinics' Experiences

in Disasters .....

Copyright 2020, by JefFrey R. BaKer, Christine E. Cerniglia, DAVIDA FINGER, Luz HERRERA, and JONEL NEWMAN.

* Jeffrey R. Baker, Associate Clinical Professor of Law, Assistant Dean of Clinical Education and Global Programs, Pepperdine School of Law; Christine E. Cerniglia, Director of Clinical and Experiential Education, Stetson University College of Law; Davida Finger, Associate Dean of Students and Rene August and Mary Jane Pastorek Distinguished Clinical Professor of Law, Loyola University New Orleans School of Law; Luz Herrera, Professor of Law and Associate Dean for Experiential Education, Texas A\&M University School of Law; JoNel Newman, Professor of Clinical Legal Education and Director of Health Rights Clinic, University of Miami School of Law. The authors developed this Article after a 2018 presentation at the AALS Conference on Clinical Legal Education, in which audience participation inspired the panelists to capture important lessons learned with recent domestic natural disasters. 
1. Loyola University New Orleans College of Law ............ 444

a. The Event ........................................................... 444

b. The Response .................................................... 445

c. The Effect in the Community ............................. 445

d. The Outcome ....................................................... 446

e. Lessons Learned .................................................. 446

i. Post-Disaster Discrimination and

Clinic Pedagogy ............................................... 447

ii. Ethical Volunteering .......................................... 449

2. Pepperdine University School of Law ......................... 452

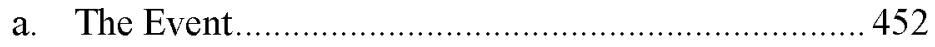

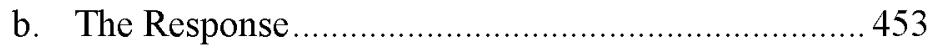

c. The Effect in the Community .................................. 457

d. The Outcome ........................................................457

e. Lessons Learned .................................................. 458

3. University of Miami School of Law ........................... 459

a. The Event ......................................................... 459

b. The Response ....................................................... 460

c. The Effect in the Community ...................................467

d. The Outcome ...................................................... 467

e. Lessons Learned .................................................... 469

4. Touro College Jacob D. Fuchsberg Law Center ............ 470

a. The Event............................................................. 470

b. The Response .................................................... 470

c. The Effect in the Community ..............................471

d. The Outcome ................................................... 472

e. Lessons Learned .................................................... 472

5. Stetson University College of Law ............................. 473

a. The Event..........................................................4 473

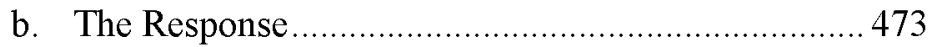

c. The Effect in the Community ................................. 475

d. The Outcome ..................................................... 476

e. Lessons Learned ................................................ 477

6. Texas A\&M University School of Law ....................... 478

a. The Event........................................................ 478

b. The Response..................................................... 479

c. The Effect in the Community ................................. 480

d. The Outcome ...................................................... 480

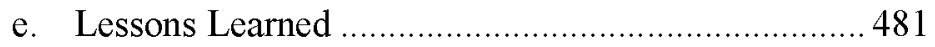

B. Paths Not Yet Taken: Potential Future Responses ............... 481

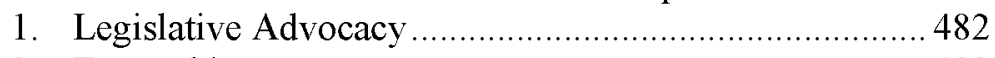

2. Externships ..................................................... 483 


\section{INTRODUCTION}

The recent onslaught of domestic natural disasters created acute, critical needs for legal services for people displaced and harmed by storms and fires. In 2017, Hurricanes Harvey, Irma, and Maria struck Texas, Florida, and Puerto Rico, displacing millions from their homes. Wildfires burned throughout California and tested the capacity of pro bono and legal aid systems across the state. At the time of drafting this Article, Hurricane Florence flooded North Carolina, and Hurricane Michael devastated the Florida Panhandle. Additionally, California suffered the largest wildfires in its recorded history. Inequality and barriers to post-disaster benefits for those who most need them arose repeatedly. Low-income and vulnerable people continue to experience significant problems accessing post-disaster resources to survive, rebuild, and return home.

In addition to the physical devastation that natural disasters cause, they also produce an onslaught of legal problems that require expertise from legal professionals. The range of legal issues that arise after a natural disaster are vast and compound problems particularly for marginalized and vulnerable populations. Once the immediate threat of danger clears, urgent needs for legal advice arise; for example, whether a tenant must pay rent on a now-uninhabitable apartment, whether someone qualifies for government assistance, or what to do if the natural disaster destroys legal documents that prove title, citizenship, ownership, or identity. People need well-trained lawyers to secure relief for these and many other challenges after the disaster.

Nonprofit legal aid organizations and pro bono attorneys have been the primary source of legal assistance after disasters. Some law school clinics have also played a role in providing legal assistance when disasters strike. ${ }^{1}$ These efforts have been diverse. Law schools have launched full-fledged clinics with a devoted budget and strict focus on disaster practice. Some took on disaster work because it represented the greatest need for existing clients and communities. Other schools shifted the focus of existing clinics to disaster needs, and still others launched temporary

1. These examples are clinics within the definitions of the ABA accreditation standards, where students represent clients under faculty supervision. STANDARDS FOR APPROVAL OF LAW SCHOOLS § 304(b) (AM. BAR ASS'N 2019). 
clinics in various forms to respond to acute needs. Some wanted to help but did not have ready relationships or resources to be responsive.

This Article builds on lessons learned by the authors' experiences responding to and living through natural disasters. The Article offers information, insights, and reflections on how law schools can develop a blueprint for community-engaged disaster response. The legal needs of vulnerable populations are not limited to times of natural disasters, but emergency situations highlight social vulnerability and the need to widen the pipeline of legal services to include law schools. Building a framework for institutional responses in the legal academy can advance and improve access to justice for vulnerable communities recovering after a disaster and can provide students with an opportunity to learn from this social justice engagement.

Part I first describes the myriad ways that disasters impact vulnerable populations most harshly, demonstrating the importance of a social justice mission in disaster response. Then, Part I presents a methodology to assess needs and capacity in the immediate aftermath of a disaster. Understanding the needs and issues arising after a disaster is essential in defining the scopes of practice that connect lawyers' capacities with client needs and goals. These needs are interdisciplinary and intersectional, so lawyers' collaboration and flexibility are paramount for effective services.

Part II provides a survey of the existing ecosystem of public and private agencies to help lawyers, law professors, and law students understand the services, resources, and bureaucracies that spring into action in the aftermath of a natural disaster. The immediate work of lawyers is to guide clients through this new world as impacted communities emerge from destruction. In their efforts to rebuild, communities must navigate through a scavenger hunt among the entities for necessary support and resources. The broader work of law professors and students is to critically examine these systems to identify gaps, insufficiencies, discrimination, and other problems that hamper just recoveries and predict inequitable distribution of post-disaster funds.

Part III examines the experiences of several law schools and clinics in recent disasters. Drawing out common issues and persistent problems, these experiences and their lessons can accelerate decision-making and preparation for legal clinics and law schools considering and designing their own responses. This Part concludes with suggestions for potential clinic models or projects, and it also identifies needs and ideas for improved law and policy that law schools may undertake. 


\section{ASSESSING LEGAL NEEDS AND CAPACITY POST-DiSASTER}

Modern natural disasters in the United States illuminate how government responses often marginalize specific populations and make them more vulnerable during these trying times. ${ }^{2}$ For example, government failures disproportionately displaced poor African American communities during and after Hurricane Katrina. In Texas, disabled people suffered the most from flooding in Hurricane Harvey. ${ }^{3}$ After Hurricane Maria, disenfranchised voters who lacked political power in Puerto Rico could not leverage equitable federal attention. Vulnerable populations are more susceptible after natural disasters, largely because of structural conditions that perpetuate inequality and result in discriminatory impact. ${ }^{4}$ To respond effectively, lawyers must first understand the unique situations and needs of vulnerable populations during disaster.

\section{A. Social Injustice Is Exacerbated by Natural Disasters}

Law schools and clinics that wish to assist should prepare students so that they understand how and why the impact of natural disasters fall most

2. See also National Center for Disaster Preparedness, Vulnerable Populations, COLUMBIA U.: EARTH INST., https://ncdp.columbia.edu/research/ vulnerable-populationsas/ [https://perma.cc/JJ66-QZLJ] (defining vulnerability as "not a fixed characteristic of an individual or a group. Rather, it is a fluid state defined by timing, the hazard at hand, circumstances, and access to different types of capital.") (last visited Feb. 23, 2019).

3. David M. Perry, Inside the Organization Saving Disabled People During Hurricane Harvey, PAC. STANDARD (Aug. 29, 2017), https://psmag.com/socialjustice/saving-disabled-people-during-hurricane-harvey [https://perma.cc/47HL9NYN]; see also Marissa Evans, After Harvey, Questions Remain About Whether Registry Helped People with Disabilities, TEX. TRIB. (Aug. 22, 2018), https:// www.texastribune.org/2018/08/22/did-state-registry-help-people-disabilities-dur ing-harvey/ [https://perma.cc/MX92-HJBJ] (describing how people with disabilities should be helped during a disaster, but the registry was criticized during Harvey).

4. Key findings in a series of reports produced by the Gulf Coast Child and Family Health Study reflect systemic health issues in those already vulnerable in a pre-disaster context suffering further health concerns post-disaster (analyzing stress and socioeconomic factors as an additional vulnerability). See David Abramson et al., Measuring Individual Disaster Recovery: A Socioecological Framework, 4 Disaster Med. \& Pub. Health Preparedness S46 (2010), https://academic commons.columbia.edu/doi/10.7916/D81G0X8X [https://perma.cc/6VEY-FG48] (noting psychological strength and a household income greater than $\$ 20,000$ as the greatest associations with positive recovery). 
harshly on those least able to bear them. Structural inequality is one driver of this disproportionately harsh impact. Impoverished people in the U.S. are more vulnerable to natural disasters due to such factors as "place and type of residence, building construction, and social exclusion. " Racially segregated housing in the South has resulted in minorities disproportionately occupying "low-lying, flood-prone, and amenity-poor segments of urban areas." Social isolation further contributes to the likelihood of death from disasters. ${ }^{7}$ Additionally, poverty, age, and disability further contribute to higher risk from disasters. People with disabilities are two to four times more likely to die or sustain injury during a disaster than those without disabilities. ${ }^{8}$ An estimated $73 \%$ of fatalities after Hurricane Katrina were people over the age of 60 , even though that same population made up only $15 \%$ of the overall population. ${ }^{9}$ Tragic stories emerged after Hurricanes Katrina and Irma about needless deaths resulting from substandard nursing home conditions, lack of preparation, and inadequate transportation services. ${ }^{10}$

5. Alice Fothergill \& Lori A. Peek, Poverty and Disasters in the United States: A Review of Recent Sociological Findings, 32 NAT. HAZARDS 89, 89 (2004); ERIC KlinenBerg, Heat Wave: A SOCIAL Autopsy of Disaster In CHiCAGo ( $2 \mathrm{~d}$ ed. 2002); F. Canouï-Poitrine et al., Excess Deaths During the August 2003 Heat Wave in Paris, France, 54 Revue d'EPIDÉMIOLOGIE SANTÉ PubliQue 127 (2006); see also Neil Reisner et al., Eight Dead from Sweltering Nursing Home as Florida Struggles After Irma, N.Y. TIMES (Sept. 13, 2017), https://www.nytimes.com/ 2017/09/13/us/nursing-home-deaths-florida.html [https://perma.cc/7XTL-Z3AW].

6. Jeff Euland \& Barney Warf, Racialized Topographies: Altitude and Race in Southern Cities, 96 GeograpHICAL ReV. 50, 50 (2010).

7. KlinenBerG, supra note 5; Canouï-Poitrine et al., supra note 5; Reisner et al., supra note 5.

8. See "Disaster Preparedness and Response: The Special Needs of Older Americans": Hearing Before the S. Special Comm. on Aging, 115th Cong. (Sept. 20, 2017) (testimony of Paul Timmons), https://www.aging.senate.gov/imo/ media/doc/SCA_Timmons_09_20_17.pdf [https://perma.cc/AKF3-9KT8].

9. Wendy Taormina-Weiss, $\bar{R}$ ights of Persons with Disabilities in America, https://www.disabled-world.com/editorials/6786854.php [https://perma.cc/84FE -DJLX] (last updated Oct. 10, 2018) (suggesting that this occurred "because many of the persons who died experienced medical, physical or sensory limitations which made them more vulnerable").

10. See Gardiner Harris, In Nursing Home, a Fight Lost to Rising Waters, N.Y. TIMES (Sept. 5, 2007), https://www.nytimes.com/2005/09/07/us/nationalspecial/innursing-home-a-fight-lost-to-rising-waters.html [https://perma.cc/K5U3-QVE3] (describing the tragedy during Hurricane Katrina at St. Rita's nursing home); Garrett Schaffel, Majority of Florida Nursing Homes Aren't Ready for Hurricanes, AARP (June 7, 2018), https://www.aarp.org/health/conditions-treatments/info-2018/florida- 
Social vulnerability plays a role in post-disaster outcomes. When disasters require evacuation, many people lack the means to evacuate or, unfortunately, are unable to do so because they have to care for someone who is physically unable to leave. ${ }^{11}$ Further, impoverished persons are far less likely to receive basic subsistence needs, such as food, after a disaster. A study conducted in the aftermath of Hurricane Sandy, for example, determined that households of lower socioeconomic status were nearly five times more likely to be worried about obtaining food. ${ }^{12}$ Homelessness post-disaster is also more prevalent among vulnerable low-income populations. ${ }^{13}$ Additionally, victims of intimate partner violence are often exposed to increased danger in a disaster because they may need to evacuate to a shelter with their abusers. ${ }^{14}$ During Hurricane Katrina, those displaced by the storm suffered a three-fold increase in intimate partner violence and a $54 \%$ increase in sexual violence. ${ }^{15}$ Thus, people who are most vulnerable have vastly increased post-disaster needs.

The legal needs of vulnerable populations are not limited to times of natural disasters, but emergency situations highlight social vulnerability and the need to develop a stronger continuum of legal services. Through advocacy, law schools can assist in filling the gap in services. ${ }^{16}$ When determining when and how to engage after a natural disaster, law schools and legal clinics should make a clear, quick assessment of their own

nursing-homes-hurricanes.html [https://perma.cc/5797-RUFB] (describing lack of preparedness for nursing homes during disaster).

11. See Mollyann Brodie et al., Experiences of Hurricane Katrina Evacuees in Houston Shelters: Implications for Future Planning, 96 AM. J. PUB. HEALTH 402 (2006).

12. Saleena Subaiya et al., A Rapid Needs Assessment of the Rockaway Peninsula in New York City After Hurricane Sandy and the Relationship of Socioeconomic Status to Recovery, 104 AM. J. PUB. HEALTH 632, 635 (2014), https://ajph.aphapublications.org/doi/full/10.2105/AJPH.2013.301668 [https://per ma.cc/C3U7-RPKB] (reporting that lower SES households were 4.7 times more likely to report being worried about food after Hurricane Sandy, possibly because they lacked transportation to reach grocery stores or relief centers outside of their immediate environments).

13. Disaster Technical Assistance Center Supplemental Research Bulletin, Greater Impact: How Disasters Affect People of Low Socioeconomic Status, SAMHSA 7 (July 2017).

14. See Young LAWYERs Div., A.B.A., 2018 ABA YLD Annual Meeting (Aug. 2, 2018), https://www.americanbar.org/content/dam/aba/administrative/young_law yers/meetings/2018/Annual/council-packet.authcheckdam.pdf [https://perma.cc/C 4TA-46GPI.

15. Id. at 11 .

16. See National Center for Disaster Preparedness, supra note 2. 
capacity and resources. The objectives likely will be to provide responsive, competent legal services alongside supervised law students while adhering to sound educational standards. This calculus will vary from school to school and disaster to disaster, and it will greatly depend upon willing faculty, students, staff, and amenable partner agencies. For law schools that have social justice missions, the opportunity to honor that mission is clear in the wake of a natural disaster.

\section{B. Identifying Legal Needs in Context}

Essential to a law school's assistance with disaster-related legal needs-whether in a law school clinic or in a remote location where the disaster occurred-is an understanding of effective planning before, during, and after disasters. Each law school should develop its own plans for disaster preparedness to assess needs and provide assistance postdisaster.

Relief organizations identify the following overlapping phases of disaster aftermath and recovery: search and rescue; emergency relief; early recovery; medium to long-term recovery, or the rehabilitation phase; and finally rebuilding and community development. ${ }^{17}$ Legal issues commonly surface throughout each phase of disaster recovery and continue for months or even years. ${ }^{18}$

To serve the community, a legal clinic should prepare to protect itself and its law practice, as well as its students, faculty, and staff. Survival and safety are the most important objectives in advance of a disaster; law schools and clinics should honor students' concerns about their own personal safety and that of their families. As a legal services provider, law

17. Corina Warfield, The Disaster Management Cycle, Global Dev. Res. CTR., https://www.gdrc.org/uem/disasters/1-dm_cycle.html [https://perma.cc/5F Z7-CHST] (last visited Feb. 24, 2018); Emergency Management in the United States, FEMA, https://training.fema.gov/emiweb/downloads/is111_unit\%204.pdf [https://perma.cc/H5N8-3UQH] (last visited Feb. 24, 2019); Stages of Disaster Management, SECTOR (Apr. 13, 2016), http://www.fp7-sector.eu/?p=578 [https://perma.cc/Y5VU-RQU3]; Melissa Crutchfield, Phases of Disaster Recovery: Emergency Response for the Long Term, NEW WORLD OUTLOOK MAG. (Mar. 2013), https://www.umcmission.org/Find-Resources/New-World-OutlookMagazine/New-World-Outlook-Archives/2013/March-April-2013/0430-Phases-ofDisaster-Recovery-Emergency-Response-for-the-Long-Term [https://perma.cc/R5U L-MRRM]; Kalpana Srivastava, Disaster: Challenges and Perspectives, 19 Indus. PSYCHIATRY J. 1, 4 (2010).

18. Warfield, supra note 17. 
clinics also have an ethical duty to safeguard client files, protect clients' rights, and ensure that clients can be contacted post-disaster. ${ }^{19}$

When a law school is located in the affected community, law clinics and perhaps local pro bono programs most often have the strongest relationships with vulnerable populations, potential client groups, and with bar leaders and legal aid organizations that will be central to coordinating post-disaster legal services. Although responders and those in need may welcome assistance from lawyers and law schools from other areas, immediate local and decentralized responses to natural disasters are often the most effective in assessing and addressing immediate needs. ${ }^{20}$ Clinics and law schools located in the disaster area may first reach out to existing clients and community partners to ask about their needs. Communication with clients is necessarily an iterative process.

It is essential that both client and counselor engage in broad and empathetic conversations about what clients need. At this stage, it is extremely important to gather wide-ranging information to fully understand what problems need to be addressed and to begin working on solutions. $^{21}$ This information is especially important because

19. ABA Comm. on Ethics and Prof'1 Responsibility, Formal Op. 482 (2018) (discussing ethical issues that may arise from disasters and emphasizing the lawyer's duties to maintain client files, records, and court dates even if the lawyer's office is destroyed or becomes inaccessible, and to be able to reach clients following a disaster). See LSC Program Disaster Checklist, NAT'L DISASTER LEGAL AID, https://www.disasterlegalaid.org/legalaidstaff/item.5418Disaster_Checklist_for_an_LSC_Program [https://perma.cc/8F9G-34BS] (last visited Feb. 9, 2019).

20. Russell S. Sobel \& Peter T. Leeson, Government's Response to Hurricane Katrina: A Public Choice Analysis, 127 PUB. CHOICE 63 (Apr. 2006); NAT'L RES. COUNCIL, FACING HAZARDS AND DisASTERS: UndERSTANDING HuMAN DIMENSIONS 136 (2006) (noting that "lifesaving efforts in a stricken community rely heavily on the capabilities of relatively uninjured survivors, including untrained volunteers").

21. See Alicia Alvarez et al., Teaching and Practicing Community Development Poverty Law: Lawyers and Clients as Trusted Neighborhood Problem Solvers, 23 CLINICAL L. REV. 577 (2017) (describing their use of iterative process in counseling clients); Barbara Wagner, Defining Key Competencies for Business Lawyers, 72 BUS. LAW. 101, 131 (2017) (describing the counseling relationship as the essence of the relationship between business lawyer and client and as essentially an iterative process under problem-solving skills); Design Thinking for Lawyers, LAWYERIST, https://lawyerist.com/strategy/innovation/ design-thinking-for-lawyers/ [https://perma.cc/6Q4H-FX7J] (last updated Jan. 14, 2019) (stating the iterative process in lawyer-client counseling gets insufficient treatment in legal academia and literature, but engaging in this process 
disaster-impacted populations-particularly those who may be marginalized and vulnerable-may be unaware of whether they are eligible for certain forms of relief or able to seek legal assistance to redress denial of benefits. Vulnerable populations often fail to recognize an issue as a need for legal services, and, indeed, low opinions of lawyers further depress the likelihood that they will seek legal assistance. ${ }^{22}$ Thus, in addition to reaching out to individual clients, clinics may hold know-your-rights workshops, question-and-answer sessions, or otherwise provide expertise in community settings to help lawyers and potential clients identify where legal interventions are most needed. ${ }^{23}$ Such efforts might include setting up a training session on FEMA and related benefits, as well as addressing the eligibility and requirements for disaster-related Food Stamps and Unemployment Assistance. ${ }^{24}$ Non-local lawyers and students can network with local clinicians, the Young Lawyers Division of the ABA, and local legal services providers, which can coordinate outreach to Red Cross Shelters and FEMA Disaster Recovery Centers. ${ }^{25}$

Typically, in the early weeks and months following a disaster, there is "a huge outpouring of relief supplies and support from the community, voluntary agencies, and government [that] result[s] in a high level of optimism about problems being dealt with and the situation improving. There is a wave of compassion, goodwill, and care. ${ }^{26}$ During this phase, many applications for relief may be filed and processed. Often, volunteers assist people in need of relief, and these volunteers may only be present in the community for a brief time and may not be experts in the potential pitfalls that can later complicate a client's case. ${ }^{27}$ Furthermore,

with clients post-disaster is necessary to cover the wide range of possible problems and solutions and provides rich educational opportunities).

22. Megan Sandel et al., The MLP Vital Sign: Assessing and Managing Legal Needs in the Healthcare Setting, 35 J. LEGAL MED. 41, 50 (2014); Lonnie Powers, Legal Needs Studies and Public Funding for Legal Services: One State's Partial Success, 101 DiCK. L. REV. 587, 595 (1997).

23. For a discussion about the iterative process, see supra text accompanying note 21 (stating that local clinics should create and maintain relationships of trust with the communities they serve); Melissa Gibson Swain \& JoNel Newman, Helping Haiti in the Wake of Disaster: Law Students as First Responders, 6 INTERCULTURAL HUM. RTS. L. REV. 133, 174 (2011).

24. See also LSC Program Disaster Checklist, supra note 19.

25. See Resources for Pro Bono Volunteers, NAT'L DISASTER LEGAL AID, https://www.disasterlegalaid.org/volunteer/ [https://perma.cc/754L-RX7R] (last visited Feb. 9, 2019).

26. Srivastava, supra note 17.

27. See generally Colleen F. Shanahan et al., Can A Little Representation Be a Dangerous Thing?, 67 HASTINGS L.J. 1367, 1369 (2016); Nina W. Tarr, Ethics, 
government agencies themselves may err on the side of interpreting eligibility rules generously during this phase, only to later seek recoupment from persons unable to make restitution. ${ }^{28}$ Law school clinicians may provide important guidance here and identify clients who need assistance with longer-term issues.

\section{Assessing Clinic Resources and Capacity}

Evaluating a clinic's capacity and resources is of singular importance. Each decision to take on a particular issue necessarily precludes taking on others. Although some clinics have full-time staff attorneys or clinical faculty who solely teach clinics, clinics are often constrained by the availability of faculty and students to do the work. ${ }^{29}$ Expanding a clinic's work to provide emergent disaster assistance requires, in essence, a law clinic to quickly develop and implement a strategic plan that incorporates disaster assistance. ${ }^{30}$ Borrowing from best practices in strategic planning, the school or program should identify the clinic's core competencies and determine where they overlap with the needs of clients in ways that are unlikely to be matched by other providers. ${ }^{31}$ Lawyers who provide assistance to vulnerable populations should keep in mind that fewer alternative providers are available for client populations who are impoverished, have limited English proficiency, or lack certain resources such as a reliable address and contact number. ${ }^{32}$

Internal Law School Clinics and Training the Next Generation of Poverty Lawyers, 35 WM. MitCHELL L. REV. 1011, 1052 (2009).

28. Davida Finger, FEMA Recoupment of Grants from Hurricane Survivors, SHRIVER CTR. POVERTY L. (July 2012), http://povertylaw.org/clearinghouse/ stories/finger [https://perma.cc/K2QM-RMEV].

29. Clinicians who have responsibilities for producing scholarship and do not have a staff attorney support model may find it more difficult to take on disaster work on top of their existing workloads. Even for those clinics that have focused their operations on disaster relief, breaks between semesters reduce capacity. In these situations, clinicians must be creative about how to support disaster efforts.

30. For an in-depth discussion of strategic planning in the business context, see Alan S. Gutterman, Business Transactions Solutions § 334 (Westlaw 2018 Update).

31. Id. $\S 334: 3$

32. See Alan Houseman, Restrictions on LSC Funded Legal Aid Programs, GEO. L. LIBR. (Mar. 19, 2015), https://blogs.commons.georgetown.edu/righton/ 2015/03/19/restrictions-on-lsc-funded-legal-aid-programs/ [https://perma.cc/FN Z2-4KN9]; The Needs of and Services for Persons with Limited English Proficiency (LEP), N.Y. ST. OfF. FAM. \& CHILD. ServS. (June 2007), https:// ocfs.ny.gov/main/reports/LEP2007.pdf [https://perma.cc/D8XU-KXJB]; Edward 
Once a law clinic or other law school entity has developed a working knowledge of where its competencies best intersect with pressing client needs, an honest consideration of capacity should ensue: how will engaging in this work impact teaching responsibilities and existing clinic workload? If an existing law school clinic is undertaking this work, how will disaster response affect services to the clinic's existing clients? How will adding new responsibilities to the clinic impact law students? Will residual disaster-related client work impact future student workload? Before embarking on providing disaster assistance, it is important for law schools and clinics to understand that FEMA claims and post-claim recoupment issues may take years to resolve; that meaningful, impactful advocacy often takes many months or even years; and that it may take months or even years to obtain basic needs, such as housing and food, for the most vulnerable populations.

Addressing systemic issues occurring throughout litigation or other policy advocacy necessarily incurs ongoing obligations to clients, the court, and the community, and these cases may take on a life and time frame of their own. In the aftermath of Hurricane Andrew in South Florida in 1992, for example, legal services advocates filed a class action against FEMA that resulted in three years of litigation. ${ }^{33}$ For more than a decade, FEMA recoupment claims post-Andrew continued to be litigated ${ }^{34}$ More recently, in Miami, the Health Rights Clinic's statewide class action

Golding et al., Is Limited English Proficiency a Barrier to Homeownership, URBAN INST. (Mar. 2018), https://www.urban.org/sites/default/files/publication/ 97436/is_limited_english_proficiency_a_barrier_to_homeownership_0.pdf [https://perma.cc/ZY4R-7KQZ] (people with limited English proficiency are less likely to own a home or have housing stability); Lindsay Satterwhite Mayberry et al., Families Experiencing Housing Instability: The Effects of Housing Programs on Family Routines and Rituals, 84 AM. J. ORTHOPSYCHIATRY 95 (2014); Natasha Pilkauskas \& Katherine Michelmore, The Effect of Income on Housing Instability and Living Arrangements: Evidence from the Earned Income Tax Credit, POVERTY SOLUTIONS U. MiCH., https://poverty .umich.edu/files/2018/09/Pilkauskas _Michelmore_EITC_Housing_Sept2018.pdf [https://perma.cc/8GLF-E7HA] (last updated Sept. 2018) (poverty and housing instability or homelessness are linked); Margot B. Kushel et al., Housing Instability and Food Insecurity as Barriers to Health Care Among Low-Income Americans, 21 J. GEN. INTERNAL MED. 71 (2006) (housing instability and food insecurity result in delays in seeking care).

33. Lockett v. FEMA, 836 F. Supp 847 (S.D. Fla. 1993).

34. See Jennifer Seidenberg, Cultural Competencies in Disaster Recovery: Lessons Learned from the Hurricane Katrina Experience for Better Serving Marginalized Communities, BERKELEY U. ONLINE RES., https://www.law .berkeley .edu/library/resources/disasters/Seidenberg.pdf [https://perma.cc/C26R26HC] (last visited Feb. 10, 2019). 
challenging the USDA and Florida Department of Children and Families' administration of disaster-related Food Stamps lasted longer than an academic year, and its work assisting the Haitian TPS-eligible community following the 2010 earthquake has continued in various aspects for a decade. Understanding at the outset how long a clinic or program's commitment might be takes on greater importance for more vulnerable client groups. Not only are vulnerable populations less likely to have access to legal assistance, but they are also in more need of coordination and some assurance of continuity of care. ${ }^{35}$

These questions and cautions should not discourage clinics from taking on such vital and important work, but they bear consideration in advance to avoid possibly significant and unforeseen adverse consequences. Considering these questions in advance and engaging stakeholders in a dialogue about them can positively impact engagement in this work in several ways. Examining the issues and anticipating the consequences prompts intentional, diligent work. Even if increased workload leads to adverse consequences, for example, the exercise of having anticipated these consequences and discussing them with stakeholders increases the likelihood that all stakeholders will have had some opportunity to plan. Finally, taking on this work, even when it creates an overload, communicates an important lesson to students: the need for these services - which often secure life-sustaining benefits - is dire and will otherwise go unmet for many community members unless lawyers step forward to serve. ${ }^{36}$

35. See sources cited supra note 32. For a description of lack of continuity of care creating a barrier in vulnerable communities in the medical context, see Institute of Medicine, America's Health Care Safety Net: InTACT BUt ENDANGERED (Marion Ein Lewin \& Stewart Altman eds. 2000) (discussing the importance of trust and continuity in healthcare providers for vulnerable populations); Lillian Gelberg et al., The Behavioral Model for Vulnerable Populations: Application to Medical Care Use and Outcomes for Homeless People, 34 Health SERV. Res. 1273 (2000) (finding regular source of care to be a predictor of improved outcomes, and lack of regular provider may result in homeless persons avoiding care).

36. See JoNel Newman \& Donald Nicolson, A Tale of Two Clinics: Similarities and Differences in Evidence of the "Clinic Effect" on the Development of Law Students' Ethical and Altruistic Professional Identities, 35 BUFF. PUB. INT. L.J. 1, 37 (2017) ("High caseloads also bring home the message that there is a dire need for legal service by many community members."). 


\section{The ECOSystem of Agencies, LAW, AND Resources AFTER A NATURAL DISASTER}

In the immediate aftermath of a natural disaster, the most useful work of lawyers is often to guide clients and communities through a new, complex world of public bureaucracies, insurance companies, contracts, and laws. As people emerge from destruction with hope to rebuild, they commence a scavenger hunt among these entities for necessary support and resources. Lawyers and law students can offer significant help to people in trauma and crisis by aiding them in understanding options, next steps, and the relationships among sources of support.

Preparing for effective response requires a sound orientation to the agencies and resources available to people harmed in a natural disaster, which are the common entities in the ecosystem of a disaster before, during, and after it strikes. Most people do not think about federal agencies, insurance policies, local ordinances, leases, and mortgages on a daily basis. During and after a natural disaster, however, affected persons must address them all at once under great stress. Even when these processes work well, they can be daunting for people in trauma, and systemic and social injustices compound the confusion, making them more overwhelming and ineffective.

Identifying partners and existing resources is another essential step to providing pro bono legal services in response to a natural disaster. In addition to federal and state agencies, a constellation of agencies and organizations routinely activate or improvise systems to provide legal services and advice to people and communities that natural disasters disrupt. These often include bar associations, legal aid agencies, volunteer lawyer programs, law schools, and pro bono lawyers. Law schools and legal clinics may accelerate their preparation and program design by considering a scope of practice that engages these intersecting resources and identifies partners with whom they can serve.

\section{A. Federal Emergency Management Agency}

The Federal Emergency Management Agency (FEMA), a unit of the Department of Homeland Security (DHS), is likely the best-known government agency that responds to natural disasters. ${ }^{37}$ In major disasters, it is often the lead agency, but it does not respond alone among federal and state governments. Every state has a state-level emergency management

37. Exec. Order No. 12127, 3 C.F.R. 376 (1979). Congress brought FEMA under the Department of Homeland Security in the Homeland Security Act of 2002. Homeland Security Act of 2002, H.R. 5005, 107th Cong. $\$ 507$. 
agency that typically coordinates with FEMA, and state governments may engage law enforcement, state benefits agencies, and other units in response to natural disasters. For individual assistance, and much public assistance, FEMA support is unavailable until the president declares an emergency, which must follow a state governor declaring an emergency for an affected area. ${ }^{38}$

The National Response Framework (NRF), a guide that DHS publishes, explains the nation's disaster response systems' structures, the mission for each coordinating entity, and the proper integration to a well-prepared response. "An effective, unified national response requires layered, mutually supporting capabilities. Individuals and communities, the private and nonprofit sectors, faith-based organizations, and all levels of government . . . should understand their respective roles and responsibilities and how to complement each other in achieving shared goals. ${ }^{.40}$ As outlined in the NRF, the level of tasks assigned to each federal and state entity corresponds to its primary focus or responsibility. For instance, the Department of Transportation prepares and coordinates the safety and security of national transportation on impacted roads; additionally, the United States Army Corps of Engineers coordinates and facilitates "the delivery of services, technical assistance and engineering expertise." "4l Under the authority of the Stafford Act, FEMA coordinates critically important post-disaster tasks, such as mass care, emergency assistance, and temporary housing. FEMA may activate its "emergency support functions" selectively by employing local partners to respond and coordinate efforts. ${ }^{42}$

In the early aftermath of a disaster, FEMA first tends to critical needs regarding survival and infrastructure alongside state and local governments. Then, it may begin to open Disaster Recovery Centers ("DRCs"), usually through a partnership with local partners like governments, churches, or schools. Ideally, DRCs are readily accessible or mobile to allow people to register for disaster benefits and directly ask

38. See id.

39. U.S. Dep'T Homeland SeC., NATional ResPonse Framework (3d ed. 2016), available at https://www.fema.gov/media-library-data/1466014682982-

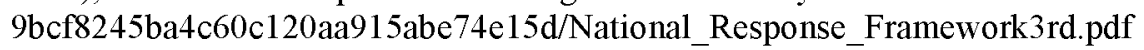
[https://perma.cc/2W46-DD45]. The NRF first published the Federal Response Plan in 1992, which was focused on federal roles, and now the most recent publication expands to include integration at the state level and with the private sector. $I d$.

40. See id. at 8 .

41. See id. at 34 .

42. See id. at 38 . 
questions to FEMA representatives, the Small Business Administration, volunteer groups, or other agencies. ${ }^{43}$ DRCs often provide one-stop shops for services like counseling, program information, disaster unemployment, funeral assistance, and disaster legal services. ${ }^{44}$

FEMA is the front-line agency for distributing federal funds for disaster relief. Most commonly, the funds come in two basic categories: Individual and Household Assistance and Public Assistance. ${ }^{45}$ The Individual and Household Assistance Program defines eligibility for available assistance in several categories, including Mass Care and Emergency Assistance, Crisis Counseling Assistance and Training, Disaster Unemployment Assistance, Disaster Legal Services, Disaster Case Management, and Individuals and Households Program (IHP).$^{46}$ IHP includes two categories of assistance: Housing Assistance and Other Needs Assistance. ${ }^{47}$

Individuals and families in immediate need after a disaster most commonly seek IHP assistance, which also represents an area where law schools and legal clinics can be particularly effective as recovery begins. Housing Assistance includes Lodging Expense Reimbursement, Rental Assistance, Repair, and Replacement. ${ }^{48}$ Other Needs Assistance includes two main categories: claims that are either dependent or non-dependent on the applicant receiving a disaster loan from the Small Business Administration. ${ }^{49}$ Non-dependent awards may be available for funeral, medical, dental, childcare, and assistance for miscellaneous items like

43. Disaster Recovery Centers, FEMA, https://www.fema.gov/disasterrecovery-centers [https://perma.cc/243E-479D] (last visited July 27, 2018) (ability to search for a DRC by entering in zip code); see also Anne Cates, Disaster Recovery Centers (Äpr. 23, 2012), https://www.fema.gov/medialibrary/assets/videos/79681 [https://perma.cc/8XLH-LVCD].

44. See Disaster Recovery Centers, supra note 43 (showing services listed with links to each entity).

45. FEMA publishes annual guides that are very helpful to individuals, local governments, and their counsel in applying for assistance and filing appeals. See Individual and Households Program Unified Guidance, FEMA (Sept. 2016), https://www.fema.gov/media-library-data/1483567080828-120 lb6eebf9fbbd7c8 a070fddb308971/FEMAIHPUG_CoverEdit_December2016.pdf [https://perma.cc/ 926P-DRSB]; Public Assistance Program and Policy Guide, FEMA (Jan. 2018), https://www.fema.gov/media-library-data/1549560260399-ea1533f $73 \mathrm{~d} 45708601 \mathrm{lb}$ e0b4leflcd8d8/Final_StateLedPAGuide_20190204(508).pdf [https://perma.cc/C MQ7-B893].

46. Individual and Households Program Unified Guidance, supra note 45, at 4 .

47. See id.

48. See id.

49. See id. at 7-8. 
chainsaws or dehumidifiers purchased or rented after the disaster ${ }^{50}$ FEMA awards that are dependent on the Small Business Administration loan applications may include assistance for personal property, moving and storage, and transportation. ${ }^{51}$ Eligibility and awards depend greatly on an individual or a household's private insurance coverage.

A disaster declaration that includes IHP typically establishes a deadline for registering and applying for various forms of assistance. ${ }^{52}$ FEMA issues an assistance award or denial, and applicants may appeal a denial or an insufficient award within 60 days. FEMA case workers and managers with relatively little transparency handle these administrative appeals. $^{53}$

For law schools and law school clinics, assisting with applications and appeals for FEMA assistance is a critical service. It has immediate effect that can fit efficiently into models of limited-scope representation. Law professors and students may staff Disaster Recovery Centers, assist local legal aid agencies, establish field clinics, or provide remote advice and counsel to clients with access to phones or the internet. Law students can effectively handle these useful, discrete matters under supervision, and these matters can advance students' skills in client counseling, case evaluation, document assessment, writing, and administrative advocacy.

\section{B. State and Local Agencies}

Each state has its own agency charged with managing emergency preparedness and response, and these agencies' jurisdictions, purposes, and capacities vary according to local and regional needs. For many states, these emergency management agencies are primarily responsible for preparedness, public relations, communication, and coordination of other state and local agencies. Fewer provide direct individual assistance, but most look to FEMA for post-disaster recovery funds for individuals.

For example, California's emergency management response agency is the Governor's Office of Emergency Services. ${ }^{54}$ This agency principally

50. See id.

51. See id.

52. In 2019, people may apply in person at a DRC, by telephone, or online.

53. See, e.g., How to Appeal a FEMA Disaster Assistance Decision, FEMA (Sept. 7, 2017), https://www.fema.gov/news-release/2017/09/07/how-appealfema-disaster-assistance-decision [https://perma.cc/KT9W-7D43]; see also Interactive FEMA Appeals Tool, NAT'L DISASTER LEGAL AID, https://www. disasterlegalaid.org/femaappeals/ [https://perma.cc/B8B2-628X].

54. See About Cal OES, Cal. Governor's Off. EMERgency Servs., http://www.caloes.ca.gov/ [https://perma.cc/4PYM-3APV] (last updated 2019). 
administers disaster preparedness, government coordination, and regulatory administration. ${ }^{55}$ It actively assists individuals through education and communication about resources potentially available via voluntary agencies, insurance, local programs, the SBA, and FEMA ${ }^{56}$ It does not provide direct financial assistance itself.

In practice, local or tribal governments usually respond first and coordinate response and recovery efforts until state or federal resources arrive ${ }^{57}$ Often, local governments do not have proper funding to launch a fulsome post-disaster response and heavily rely upon state coordination. Local governments may be good partners for law schools and legal clinics to coordinate and promote programs because they are proximate to local needs, may have fewer resources, and may have more accessible networks for law faculty and students.

\section{The American Bar Association and State Bar Associations}

Law schools and legal clinics may find quick access to established networks by contacting the Young Lawyers Division (YLD) of the American Bar Association (ABA) or state bar associations in preparation for or in response to natural disasters. ${ }^{58}$ Through an agreement with FEMA, the YLD coordinates pro bono disaster legal services after a disaster. ${ }^{59}$ The YLD first provides a link to a webpage that is specifically for the declared disaster zone, which outlines resources for attorneys to sign up and volunteer to provide free legal services. ${ }^{60}$ The YLD also usually coordinates a weekly disaster phone call, which includes a report from Red Cross, the many DRCs, legal aid offices, and law clinics. This weekly phone call informs everyone about the concerns on the ground and provides a headcount of those in shelters or in need. Many jurisdictions

55. See, e.g., For Individuals and Families, CAL. GOvernoR's OFF. EMERGENCY SERVS., http://www.caloes.ca.gov/for-individuals-families [https://per ma.cc/3QJJ-TZND] (last updated 2019).

56. See id.

57. See 42 U.S.C. $\$ 5170$ (a) (2012).

58. For a comprehensive history of ABA Young Lawyers Division's Disaster Legal Services Program, see Andrew Jack VanSingel, The Calm After the Storm: 45 Years of the ABA Young Lawyers Division's Disaster Legal Services Program, 35 TOURo L. REV. 1019 (2019).

59. See Disaster Legal Services Fact Sheet, FEMA, https://www.fema.gov/ media-library/assets/documents/24413 [https://perma.cc/JY9T-2RVR] (last updated Apr. 2019).

60. See Disaster Relief, A.B.A. (Oct. 10, 2018), https://www.american bar.org/groups/committees/disaster/disaster_relief.html\#5 [https://perma.cc/586RSE62]. 
have employed a disaster hotline for questions related to disaster claims and referrals to pro bono attorneys. ${ }^{61}$ The YLD and the state bar associations usually coordinate this hotline, but they rely upon volunteer attorneys.

From 2017-2018, the YLD coordinated several national conference calls to respond to Hurricanes Harvey, Maria, and Irma, the fires in California, and the tropical storms in American Samoa. The conference calls and subsequent introductions created critical networks of willing and able attorneys and clinics. The YLD does not provide direct legal services itself, but it importantly connects pro bono providers with attorneys and clients in the field. Law schools and clinics may find quick, efficient means of accessing clients and projects in affected areas by connecting with the YLD, which then can accelerate introductions to programs in the field.

Law schools and legal clinics aiming to contribute pro bono legal services may find efficient coordination through state bar associations' coordinating efforts. State bar associations serve a central role in coordinating pro bono legal assistance in the wake of major disasters. The Mississippi Bar organized young lawyers for Disaster Legal Assistance in 2005 in the days after Hurricane Katrina, focusing pro bono efforts largely on landlord-tenant disputes where tenants returned from evacuations to find landlords occupying their homes after the landlords lost theirs. ${ }^{62}$ The Mississippi Supreme Court issued emergency orders to permit foreign lawyers to provide limited pro bono services to people displaced by the storm. $^{63}$

In 2017, the Texas Supreme Court issued a similar order permitting foreign attorneys to provide pro bono, storm-related legal services when sponsored by Texas attorneys. ${ }^{64}$ For these and other attorneys, the State

61. Surviving a Disaster, A.B.A. (2013), https://www.american bar.org/content/dam/aba/administrative/disaster/state_bar_association_coop_tem plate_revised_final2-2013.authcheckdam.pdf [https://perma.cc/VCC2-XBNW].

62. Disaster Legal Assistance, Miss. B. Ass'N (Spring 2016), https:// www.msbar.org/inside-the-bar/young-lawyers-division/disaster-legal-assistance/ [https://perma.cc/W7SZ-C8BK].

63. Out of State Lawyers to Assist Victims of Hurricane Katrina, ST. Miss. JUDICIARY (Sept. 9, 2005), https://courts.ms.gov/news/2005/09.09.05probono.php [https://perma.cc/ASB7-XKMU].

64. Amended Emergency Order After Hurricane Harvey Permitting Out-ofState Lawyers to Practice Texas Law, TEX. Jud. BranCH (Aug. 30, 2017), http://www.txcourts.gov/media/1438820/179101.pdf [https://perma.cc/3MNRTX5Z]. 
Bar of Texas provided rich and useful educational materials for lawyers who needed quick orientation and preparation for disaster response. ${ }^{65}$

In response to the historic wildfires of 2017 and 2018, the State Bar of California's Office of Legal Services coordinated regular conference calls with various local governments, county bar associations, legal aid agencies, and clinics. ${ }^{66}$ The California Bar also hosted hotlines and posted information for consumers and potential clients affected by the wildfires. ${ }^{67}$

In Florida, the response to Hurricanes Irma and Michael required coordinated efforts by the ABA, the Florida Bar, and volunteer attorneys across the state. More than 500 attorneys volunteered to assist with answering legal questions. ${ }^{68}$ This outreach effort required layers of communication between bar officials, the Young Lawyers Division, and pro bono coordinators. ${ }^{69}$

The ABA and state bar associations are essential to building networks of pro bono attorneys, law schools, and legal aid agencies. They can access members and accelerate communication with a great number of lawyers more quickly than ad hoc efforts in the rushed moments after a disaster. Law schools may advance their efforts by engaging with local and state bar associations before or immediately after a disaster to identify needs and responsive networks.

\section{Legal Aid}

Legal aid agencies, most often funded by the Legal Services Corporation (LSC) or state agencies that manage funds from interest earned on lawyer accounts, are often the first to provide pro bono legal

65. Disaster Relief Resources, ST. B. TEX., https://www.texasbar.com/ Content/NavigationMenu/ForThePublic/DisasterReliefResources1/default.htm [https://perma.cc/3XTV-Q9A3] (last visited Dec. 1, 2019).

66. E-mail from Elizabeth Hom, State Bar of Cal., Office of Legal Services to Jeffrey R. Baker (Feb. 6, 2019) (on file with author)

67. Legal Help for People Impacted by California Fires, ST. B. CAL., http://www.calbar.ca.gov/Public/Need-Legal-Help/Free-Legal-Help/Legal-HelpAfter-Disaster [https://perma.cc/Y4QC-78UT] (last updated Nov. 27, 2018).

68. Monika Gonzalez, The Florida Bar, FEMA Prepare to Help Hurricane Irma Victims, LAW.COM (Sept. 8, 2017), https://www.law.com/sites/almstaff/2017/09/ 08/the-florida-bar-fema-prepare-to-help-hurricane-irma-victims/?slreturn=201901 27065911 [https://perma.cc/MZX2-FU7B].

69. See Florida Civil Legal Storm Aid Resources, FLA. B. Found., https://the floridabarfoundation.org/storm-aid [https://perma.cc/2PUT-P5AH] (last visited Oct. 16, 2019). 
services to the most vulnerable people affected by a natural disaster. ${ }^{70}$ They often have the best existing networks and have the best ability to triage needs and deploy systems to assist people in great need. LSC-funded legal aid offices have restrictions on clients they can serve and matters they can handle, from income caps to immigration status. ${ }^{71}$ Law schools and legal clinics may be able to partner effectively with them to expand the reach of public interest, pro bono legal services.

When seeking partners in disaster areas, however, eager law schools and legal clinics should be patient and flexible with legal aid colleagues on the ground. Often, the legal aid lawyers are victims in recovery themselves. ${ }^{72}$ The disaster may literally and figuratively inundate victims, so it can take days or weeks to determine priorities and to establish systems for intake, evaluation, and referral. Most likely, legal aid agencies will have the greatest volume of clients needing direct legal services and will have the greatest need for pro bono volunteers to receive clients and cases by referral.

Law schools and legal clinics can amplify their effects with greater efficiency by establishing partnerships - perhaps in advance of local disasters-and creating pipelines for referrals and field clinics. When LSC-funded agencies may have limitations on whom they can serve and what matters they can take, law school clinics may be well-positioned to accept clients and cases who do not fit within their restrictions. This type

70. For example, Texas RioGrande Legal Aid and Lone Star Legal Aid responded immediately with systems and services in the aftermath of Hurricane Harvey. In 2018, Neighborhood Legal Services of Los Angeles County had received an LSC grant to establish a disaster relief practice just days before the Woolsey Fire assailed Los Angeles County. Notes on file with the authors.

71. See generally How We Work, Legal SERvs. CORP., https://www.lsc .gov/what-legal-aid/how-we-work [https://perma.cc/8H3D-NZEZ] (last visited Dec. 1, 2019) (describing LSC's work and grantmaking process).

72. In the immediate wake of Hurricane Harvey in 2017, the Houston offices of Lone Star Legal Aid burned after an explosion probably caused by a gas leak. See Debra Cassens Weiss, Apparent Explosion and Fire Damage Legal Aid Office in Houston, ABA J. (Aug. 29, 2017), http://www.abajournal.com/news/article/ apparent_explosion_and_fire_damage_legal_aid_office_in_houston [https://per ma.cc/RRQ $Q 3-A 6 D R]$; Clarissa Ayala, Lone Star Legal Aid's Houston Office Is Up and Running - In New Digs, LONE STAR LEGAL AID (Oct. 5, 2017), https:// lonestarlegal.blog/2017/10/05/press-release-lone-star-legal-aids-houston-office-isup-and-running-in-new-digs/ [https://perma.cc/4KW7-5GBM] (describing how Lone Star Legal Aid lawyers and staff worked in ad hoc offices at their homes, coffee shops, disaster recovery centers, Red Cross shelters, and resource fairs around Houston and the surrounding counties before relocating to space donated by the private bar in the midst of disaster recovery). 
of overlap strategy helps broaden outreach efforts with larger impact into the community, which may help convince many in the community to stay and help rebuild. These cases may fit a clinic's existing clientele and can offer work suitable for law students in supervised practice.

\section{E. Pro Bono Lawyers}

Volunteer lawyers are a critical component of the response to natural disasters, simply because the volume of claims can overwhelm legal aid agencies and existing systems. Nearly 800,000 people filed applications for FEMA assistance in Texas after Hurricane Harvey, followed by millions more in Florida and Puerto Rico. ${ }^{73}$ That scale renders volunteer lawyers from the private bar essential to adequately provide access to legal services.

Volunteer lawyers may be able to fill gaps with their areas of expertise that legal aid agencies typically do not serve-especially with insurance claims and litigation, housing, consumer protection, bankruptcy, and business interruption, among others. In 2017 and 2018, the State Bar of California received 600 responses from lawyers volunteering in reaction to the wildfires. ${ }^{74}$

Existing pro bono programs with volunteer lawyers may direct their resources and attention to disaster response, or state bar associations or others may launch specialized programs to focus on a single disaster. As explained more fully below, law schools may also launch their own programs within their own networks.

\section{F. Resources Beyond Legal Needs}

No discrete legal issue exists in isolation from the rest of a client's life. Accordingly, a holistic approach that includes referrals to social services and other resources for immediate and intermediate needs best serves clients. The best practice for law schools or legal clinics is to be familiar with nonprofits, local agencies, religious communities, medical and mental health providers, and others who may meet needs beyond legal services, especially during disaster times. ${ }^{75}$

73. Historic Disaster Response to Hurricane Harvey in Texas, FEMA (Sept. 22, 2017), https://www.fema.gov/news-release/2017/09/22/historic-disaster-responsehurricane-harvey-texas [https://perma.cc/Z968-NSKP].

74. E-mail from Elizabeth Hom, State Bar of Cal. Office of Legal Services to Jeffrey R. Baker (Feb. 6, 2019) (on file with author).

75. For example, National Voluntary Organizations Active in Disaster (VOAD) - a coalition of nonprofits - has mobilized in response to natural 
Existing law school clinics likely have networks of partners and collaborating agencies for referrals. Coordinating responses with these organizations can deepen responses to real needs. These organizations can also serve as mutual referral partners with a legal clinic or law school program, providing clinics with clients and resources for clients' needs beyond legal advice and advocacy.

Law schools and legal clinics can play a vital and useful role in responding to natural disasters by expanding access to justice and pro bono legal services to marginalized and vulnerable communities that these disruptions disproportionately affect. By forging creative relations and engaging existing systems, agencies, and organizations, law schools and clinics can maximize effect, even with limited resources. These initiatives can be temporary and improvised or permanent and sophisticated. They can advance sound professional pedagogy for law students and serve clients with excellence.

\section{TeSted Models for LAW SCHOOL AND LEGAL CliniC ReSPONSES TO NATURAL DISASTERS}

Law schools have played important roles in filling gaps in disaster legal services. Through their pro bono and clinical programs, law schools give students an opportunity to perform relief work. Law schools can mobilize alumni networks and expert faculty, and they often have useful relationships with legal-services agencies, volunteer lawyer programs, community organizations, and local governments. With these ready resources, law schools and law school clinics can contribute valuable and meaningful services in response to natural disasters.

\section{A. Law Schools and Legal Clinics' Experiences in Disasters}

This Part provides several examples of law schools and clinics in action following recent natural disasters, followed by several examples of models and projects that law schools could consider deploying in their own communities and contexts. These examples illustrate potential contributions from law schools and legal clinics. All of them require collaboration with external partners; all of them will require advance planning by law schools or very nimble academic and administrative responses. The best preparation for natural disasters is advance

disasters since Hurricane Camille in 1969. National VOAD is the primary point of contact for voluntary organizations with FEMA. See Voluntary Organizations Active in Disaster, READY, https://www.ready.gov/voluntary-organizationsactive-disaster [https://perma.cc/6NV4-3ET7] (last visited Feb. 25, 2019). 
preparation, having a plan and model in place for the inevitable, acute needs. Considering these roles and model responses can advance a law school's readiness to respond to community needs and to create effective, assessable pedagogy.

\section{Loyola University New Orleans College of Law}

Loyola University New Orleans College of Law is one of the most active law schools in disaster relief efforts. In this section, we discuss its principal efforts and the lessons learned that have informed post-disaster relief methods at law schools across the country.

a. The Event

In 2005, Hurricanes Katrina and Rita hit the Gulf Coast, and those storms-together with the failures of the levees and the inadequate government response at all levels-devastated the Louisiana and Mississippi Gulf Coasts. Articles discussing the 2005 Gulf Coast hurricanes with wide-ranging commentary on the structural failures, barriers to rebuilding, and what are called "lessons learned" flood the literature. ${ }^{76}$ Arguably, the most important post-disaster lessons were not learned following the Gulf Coast hurricanes. ${ }^{77}$ As hurricanes, wildfires, and other storms have pummeled the United States, recoveries have been marked by the same disparities that are now synonymous with Hurricanes Katrina and Rita.

Still, reflecting nearly 14 years later from the perspective of a post-disaster law clinic, two points referenced extensively in the "lessons learned" discussions emerge for emphasis and close consideration: (1) access to disaster legal services and post-disaster recovery should be taught by law schools and law clinics with a central focus on disparities associated with race, poverty, and gender; and (2) post-disaster volunteer-lawyering efforts require careful planning and consideration, as with any other component of post-disaster relief.

76. See generally William P. Quigley, What Katrina Revealed, 2 HARV. L. \& POL'Y 361 (2008).

77. See, e.g., Charles D. Ellison, Race and Class Are the Biggest Issues Around Hurricane Harvey and We Need to Start Talking About Them, RoOT (August 29, 2017), http://www.theroot.com/race-and-class-are-the-biggestissues-around-hurricane-1798536183 [https://perma.cc/M2WE-LXYJ]. 


\section{b. The Response}

After the 2005 Gulf Coast hurricanes, Loyola University New Orleans College of Law created the Katrina Clinic. ${ }^{78}$ The storms displaced the entire Loyola University New Orleans College of Law to Houston, Texas, and from there, the University of Houston Law Center hosted the law clinic. Law clinic students and faculty-in association with Lone Star Legal Aid and the University of Houston-worked in Disaster Relief Centers to assist those displaced by Hurricane Katrina who had temporarily settled in Houston. Loyola University New Orleans returned to its New Orleans campus in spring of 2006.

For the next three years, the Katrina Clinic operated from its home campus as a part of the overall Law Clinic. The Katrina Clinic Director and staff attorneys operated the clinic, using an all-volunteer model and incorporating law student volunteers from Loyola as well as law students from around the country. ${ }^{79}$ This model served its purpose during a chaotic, unstructured, and, by all accounts, desperate post-disaster time.

\section{c. The Effect in the Community}

The Katrina Clinic handled many hundreds of individual cases related to housing, contractor fraud, distribution of disaster dollars, and insurance alongside litigation against local, state, and federal governmental agencies for inequitable post-disaster policies ${ }^{80}$ For example, the Katrina Clinic, with co-counsel, brought a class action lawsuit that challenged both the termination of rental assistance and FEMA's widespread recoupment practices. The suit resulted in a $\$ 2.65$ million settlement on behalf of those who were wrongfully terminated from rental assistance. ${ }^{81}$ The Katrina Clinic continued to advocate on these FEMA issues for a number of years, even after the case settled and while FEMA recoupments were still ongoing. ${ }^{82}$ The Katrina Clinic also provided informational resources around the community on many different post-disaster topics and served

78. For a detailed description of the Katrina Clinic, see Davida Finger et al., Engaging the Legal Academy in Disaster Response, 10 SEATTLE J. SOC. JUST. 211 (2011) The description of the Katrina Clinic here is drawn from that article.

79. Id. at 217.

80. Id.

81. See Complaint, Ridgely v. FEMA, No. 07-2146, 2007 WL 1728724 (E.D. La. June 13, 2007); Ridgely v. FEMA, 512 F.3d 727 (5th Cir. 2008).

82. Davida Finger, FEMA Recoupment of Grants from Hurricane Survivors, ClEARINGHOUSE COMMUNITY (July 2012), http://povertylaw.org/clearinghouse/ stories/finger [https://perma.cc/QXQ2-7AR7]. 
as a reliable resource for up-to-date information on a number of post-disaster issue areas.

Beyond the numbers of cases and dollars won through settlements and court judgments, the unique role of the Katrina Clinic is perhaps the lasting effect it had in the disaster-impacted community. The Katrina Clinic served as a dedicated, free legal services provider for low-income people impacted by disaster. The Katrina Clinic model, with institutional support, is one that can be widely replicated in other post-disaster contexts.

\section{d. The Outcome}

In 2009, organizers discontinued the Katrina Clinic model in favor of founding a new Loyola Law Clinic offering, the Community Justice section. The Community Justice section, which works with law clinic student practitioners, continues to handle post-disaster cases as part of its newly created housing, government accountability, and civil rights docket. Other Loyola Law Clinic sections have also handled post-disaster matters, such as property and family law issues.

\section{e. Lessons Learned}

The lessons learned, discussed, and agonized over following the Katrina Clinic experience are, put simply, vast. ${ }^{83}$ One slice taken from the tremendous range of lessons learned focuses on the negative-the discriminatory distribution of rebuilding dollars for homeowners as a lens through which clinic faculty can focus post-disaster teaching. The other lesson learned focuses on a tremendous positive - the Student Hurricane Network's (SHN) efforts to recruit and mobilize law student volunteers from around the country.

83. See, e.g., William P. Quigley, A Letter to Social Justice Advocates: Thirteen Lessons Learned by Katrina Social Justice Advocates Looking Back Ten Years Later, 61 Loy. L. REV. 623 (2015); Bill Quigley, The Katrina Pain Index 2016 by the Numbers, COMMON DrEams (Aug. 22, 2016), https://www. commondreams.org/views/2016/08/22/katrina-pain-index-2016-numbers-race-and -class-gap-widening [https://perma.cc/7GDE-FT39]; Quigley, supra note 76; Stacy E. Seicshnaydre, How Government Housing Perpetuates Racial Segregation: Lessons from Post-Katrina New Orleans, 60 CATH. U. L. REV. 661, 674 (2011); Judith Browne-Dianis \& Anita Sinha, Exiling the Poor: The Clash of Redevelopment and Fair Housing in Post-Katrina New Orleans, 51 How. L.J. 481, 490 (2008); NAOMI KleIN, THE SHOCK Doctrine, PART VII (2007). 


\section{i. Post-Disaster Discrimination and Clinic Pedagogy}

First, in the context of post-disaster lawyering, scrutinizing the ways that race, poverty, gender, and their intersections play into post-disaster policies is paramount in considering clinic pedagogy. Highlighting the procedures and calculation methods to distribute post-disaster benefits to homeowners following Hurricanes Katrina and Rita is instructive in terms of understanding the botched way post-disaster benefits distribution occurred. Using federal funds, the State of Louisiana made rebuilding grants to homeowners through the Road Home Program, which was based on the lower of a pre-storm home value or estimated cost of damage. Eventually, the data proved what anecdotally had been known from the beginning, that African Americans were more likely than whites to have their Road Home grants based upon the much lower pre-storm market value of their homes, rather than the estimated cost to repair damage. ${ }^{84}$

Civil rights organizations and African American homeowners sued the State of Louisiana and the United States Department of Housing and Urban Development (HUD) for the distribution of post-disaster funds in a racially discriminatory manner. ${ }^{85}$ The lawsuit alleged that the formula used to allocate post-disaster grants to homeowners had a discriminatory impact on thousands of African American homeowners. ${ }^{86}$ Ultimately, the lawsuit settled in favor of the homeowners and required the State of Louisiana and the HUD to provide compensation in the amount of $\$ 62$ million to 1,500 homeowners. $^{87}$

For law school clinics engaged in post-disaster work or considering undertaking post-disaster cases, this example serves as a critical reminder that clinic pedagogy should approach post-disaster work through a justice and equity lens. The social vulnerability of individuals and communities

84. Complaint for Declaratory and Injunctive Relief, Greater New Orleans Fair Housing Action Ctr. v. United States Dept. of Housing \& Urban Dev., No. 1:08-cv-01938 (D.D.C. Nov. 12, 2008), available at https:// www.clearinghouse.net/chDocs/public/FH-DC-0004-0001.pdf [https://perma.cc /6YCK-APGW].

85. Id.

86. See Seth Weingart, Who's to Blame?, GREATER NEW OrLeAns FaIR HOUSING ACTION CTR. (Apr. 5, 2013), http://www.gnofairhousing.org/category /road-home/ [https://perma.cc/4PSC-X9QH].

87. Civil Rights Organizations Settle Hurricane Katrina Housing Discrimination Case Against HUD and Louisiana, LEGAL DEF. \& EDUC. Fund (June 5, 2011), https://www.naacpldf.org/update/civil-rights-organizations-settlehurricane-katrina-housing-discrimination-case-hud-louisiana/ [https://perma.cc/3 R8A-3NL6]. 
and the ways that crises exacerbate structural discrimination post-disaster must be understood and well-considered in planning and preparation for access to justice through targeted legal services. ${ }^{88}$ Clinic pedagogy should include instruction about recent post-disaster litigation to demonstrate ways that the government's approach has failed certain disaster survivors, whether or not the courts have agreed. ${ }^{89}$ Clinic pedagogy should also consider the perspective of disaster survivors, especially those from vulnerable demographics. ${ }^{90}$ The various models discussed below serve as useful examples for ways to incorporate social vulnerability into clinical teaching. By learning about and doing post-disaster work through an optic that elevates race, gender, and poverty, law students should be better equipped to understand and serve those who will have the most difficult post-disaster experiences. This exposure and engagement must surely be beneficial to working toward dismantling oppressive and discriminatory post-disaster policies and procedures in the long run.

88. See supra Part I. This reality demands that advocates plan and call for equitable distribution well in advance to avoid the systemic problems that have plagued post-disaster fund distribution. See From Surviving to Thriving: Equity in Disaster Planning and Recovery, CtR. Progressive Reform, http:// www.progressivereform.org/survivingthriving_main.com [https://perma.cc/7V2 6-2A8R] (last visited Feb. 25, 2019).

89. See, e.g., McWaters v. FEMA, 436 F. Supp. 2d 802 (E.D. La. 2006); Watson v. FEMA, No. 06-20651, 2006 WL 3420613 (5th Cir. Sept. 6, 2006); Ridgely v. FEMA, 512 F.3d 727 (5th Cir. 2008); Johnson v. FEMA, 393 Fed. Appx. 160 (5th Cir. 2010) aff'g No. 09-3409, 2009 WL 1208639 (E.D. La. May 1, 2009); Carraway v. United States ex rel. Fed. Emerg. Mgt. Agency, CIV. A. 09-1526, 2010 WL 2737161 (W.D. La. July 9, 2010); Pride v. FEMA, No. 1:11CV22-HSO-JMR, 2013 WL 6048753, (S.D. Miss. Nov. 15, 2013); Konashenko v. FEMA, No. 12-CV-3034(SJF)(WDW), 2014 WL 1761346 (E.D.N.Y. Apr. 29, 2014); La Union del Pueblo Entero v. FEMA, 141 F. Supp. 3d 681 (S.D. Tex. 2015); People's Workshop, Inc. v. FEMA, CV 17-107-JWDRLB, 2018 WL 1532196, (M.D. La. Mar. 28, 2018); Santos v. FEMA, CIV. NO. 18-40111-TSH, 2018 WL 4168993 (D. Mass. Aug. 30, 2018).

90. Candace Bernd, No Toilet, No Ventilation: Prisoners Describe Horrific Conditions in Harvey's Flood Zone, TRUTH-OuT (Sept. 8, 2017), http://www.truthout.org/news/item/41874-no-toilet-no-ventilation-prisoners-describe-horrificconditions-in-harvey-s-flood-zone [https://perma.cc/L542-23MG]; THE SOUTH End Press Collective, What Lies Beneath: Katrina, Race, and the State OF THE NATION (2007); Jordan FLAHERTY, FloOdLINES: COMMUNITY AND Resistance from Katrina to the Jena SiX (2010); Gender and Disaster Resources, INCITE, https://incite-national.org/gender-disaster/ [https://perma.cc/8 J8T-4QTF] (last visited Feb. 25, 2019). 


\section{ii. Ethical Volunteering}

Well-intentioned and eager volunteers can either be useful assets in disaster recovery or additional burdens and distractions to already stressed providers in the field. Short-term enthusiasm will quickly meet tough realities; therefore, humble, creative, and flexible approaches to volunteering are essential. These approaches are often improvised and evolving responses that defy orderly planning and easy execution. Loyola's experience through several southern hurricanes has yielded valuable insight into effective, ethical volunteering.

When Hurricanes Harvey, Irma, Maria, and Nate hit in 2017, the clinics at Loyola worked with clinic faculty from around the United States to help organize a case distribution system for those interested in assisting with disaster recovery legal needs and in being trained to do so. ${ }^{91}$ Working directly with legal service organizations in impacted communities, the network of volunteers coordinated by Loyola Law Clinic distributed pro bono cases to law school clinicians. Clinical faculty from around the country came forward for joint trainings and to post-disaster discussions on case work. Some of these clinical faculty accepted new post-disaster cases into existing dockets, and others created new clinical offerings to focus on a post-disaster docket. ${ }^{92}$

As part of this 2017 effort regarding national clinical work post-disaster, former leaders from Student Hurricane Network, reflecting on SHN's work, offered written best practices on ethical volunteering, described in part below, to help guide future post-disaster volunteer efforts. ${ }^{93}$ SHN's use of law student volunteers after Katrina demonstrates

91. See Bill Quigley, Warning Letter to Harvey and Irma Survivors from Katrina Survivor, NEW ORLEANS AGENDA (Sept. 14, 2017), https://myemail. constantcontact.com/Bill-Quigley--Warning-Letter-to-Harvey-and-Irma-Survivors -from-Katrina-Survivor.html?soid=1011087220895\&aid=GkzSj_6vP8Y [https:// perma.cc/93JM-WJ49].

92. See discussion on Pepperdine infra note 96.

93. AlLison Korn ET al., LaW STUdENT TRIPS to PROVIDE ASSISTANCE IN HuRRICANE AFFECTED AREAS: LesSONS LEARNED By THE STUdENT HuRRICANE NETWORK 2005-2009 (2017) (on file with Davida Finger and published here with permission of the authors). What eventually became known as the Student Hurricane Network (SHN) started as a collection of local law students searching for the best way to volunteer and coordinate the many requests for volunteering that were coming in following the hurricanes. Between 2005 and 2009, SHN coordinated over 5,500 law student volunteers from across the United States to help provide assistance. Law student volunteers worked on large-scale projects that required far greater numbers than could have otherwise been provided by the existing local capacity of attorneys and law students. 
a novel way to engage with post-disaster work. The Gulf Coast hurricanes should be remembered for the way that an organized and well-run volunteer legal services program can make tremendous positive impact. SHN developed suggestions for best practices that were tested in the field. The following are a few guidelines from their documented experiences:

Partnering. Connect with attorneys and other folks on the ground for legal assistance and recovery, and let them lead the way in terms of identifying needs. SHN tried to partner with people rather than organizations -- that is, especially in [Mississippi], where overburdened legal services orgs were wary of law student interventions, we allied ourselves with individual lawyers within the organizations who could then serve as ambassadors once a project went well. Local programs will need to know (at least generally) dates and how many work days a team of student[s] will have on the ground and whether a supervising professor/attorney will accompany them. This helps the organization have a much better chance of identifying appropriate projects. Then, it's essential to minimize (and centralize) contact regarding logistics of student trips - as much as possible do not rely on the host organization for help figuring out where to stay and how to rent a car.

Centralize logistics handler(s). Ideally these would be students identified so that the legal service providers don't have to deal with $100+$ law schools asking to help. A few students were the local/regional point people within SHN to liaise with the service providers around trip dates, finding lodging, directions, placements at service organizations, orientations, etc. Developing centralized logistics handlers will also help to define the requirements and match numbers for students and trips. Do not underestimate how overzealous (and well-intentioned) folks seeking to come help from afar can be quickly viewed as a burden.

Identify student liaisons at each law school or other institutions. This will ensure consistent point people for the centralized logistics handler(s) wishing to get involved or conduct a student trip to [Texas or Florida]. These liaisons can be the information gatherers and reporters at their institutions and identify and support their student volunteers' unique needs.

Focus students' efforts to fill gaps in legal assistance Determine how to lawyer in the "fringe," rather than adding to 
extensive pro bono corps already doing insurance matters, FEMA inquiries, etc.

Ideas for student work. Problems and challenges for low-income residents get immeasurably worse in the aftermath of a disaster. FEMA claims, traditional legal aid services, housing issues (including discrimination, landlord/tenant), immigration, consumer rights and fraud issues, voting rights, criminal defense are all critical post-hurricane or other disaster event. If residents are displaced because they are unable to get adequate and safe housing, their return home may face legal hurdles from a variety of sources. . . . ${ }^{94}$

Accountability. Greater accountability for promised work/research occurs when faculty supervisors from the law students' own institution are committed to working with those students, both when doing remote research and on the ground research or other projects.

Resourcing. SHN initially used faith-based centers to house student volunteers, but later transitioned to fundraising so that institutions or other small grants could pay for some kind of hotel/rental housing and free up the faith-based centers - and their staff and members - to spend their time and energy on those who lost their homes.

Mobilizing and Collaboration. SHN took a first step toward national mobilizing by sponsoring a gathering at 2005 Equal Justice Works conference/job fair in Washington, D.C. Making use of conference calls, collaborative software (such as GoogleDocs), and group chat [is] essential to planning in between in-person meeting or trips, and this in-person convening helped set those organizing efforts in motion. Other ideas include local/regional public interest fairs, regional clinical conferences, and AALS gatherings.

Trip Orientations. In 2006, SHN began organizing mandatory student orientations in New Orleans during winter and spring

94. For an overview of the types of projects and needs that can arise in the wake of a hurricane, visit the SHN annual reports. See Library, SHN, https://www.studentjustice.org/library [https://perma.cc/37LA-WKHM] (last visited Oct. 16, 2019). 
breaks. These orientations would take place on Sunday evenings before law student volunteers would begin their work on Monday mornings. These orientations focused on identifying social justice, environmental justice, and racial justice issues at play in the aftermath of Hurricanes Katrina and Rita, provide community lawyer tips, role play professional responsibility scenarios, etc. These orientations were well-received by students and service providers and helped to frame the trip. They also allowed volunteers to meet each other prior to beginning their work. Generally, relationships and trips were smooth, but it is worth reinforcing to students they represent their profession, law school, and themselves during these trips.

Sustainability of Trips. The requirements and needs as well as the interest in pro-bono trips will spike early and fall off naturally. Let the needs and requirements be the guide for these trips. Assess the value of doing more trips or curtailing participation based on the needs of local attorneys. ${ }^{95}$

Although the large scale and extended timeframe of the SHN model was unique to the specific needs of the 2005 Gulf Coast storms, this particular model is certainly replicable, albeit on what are likely to be much smaller scales. The suggested best practices serve as a useful tool for all postdisaster volunteer lawyering work regardless of number of volunteers or location.

\section{Pepperdine University School of Law}

Pepperdine University School of Law has engaged in disaster relief efforts in its community and across the country. This section offers an overview of its work.

\section{a. The Event}

In late 2017, Hurricane Harvey slammed into the Texas Gulf Coast and displaced hundreds of thousands of people. Pepperdine, in Southern California, initiated efforts to explore remote services and partnerships in Texas. ${ }^{96}$ First as an internal pro bono project, then as a one-semester,

95. KORN ET AL., supra note 93.

96. Documentation and materials for the Pepperdine projects and programs discussed here are available from the author, Jeffrey R. Baker, who directed the Disaster Relief Clinic at Pepperdine. 
temporary clinic, Pepperdine hoped to serve people in need and also to prepare the school for inevitable natural disasters in its own vulnerable region. Soon after, the Thomas Fire afflicted nearby Ventura County, at that time the largest wildfire in California's modern history. ${ }^{97}$

In November 2018, after Pepperdine wrapped up its first iteration of its Disaster Relief Clinic, the Woolsey Fire-the largest fire in Los Angeles County history-burned over 95,000 acres, including Pepperdine University's campus and its hometown of Malibu. ${ }^{98}$ The day after the fire swept through campus, Pepperdine launched its second iteration of the Disaster Relief Clinic.

\section{b. The Response}

The Disaster Relief Clinic has included at least four distinct models of practice that have evolved over the needs of three major natural disasters. Every mode of practice and teaching depended on critical partnerships with other agencies in diverse communities. The Pepperdine Disaster Relief Clinic has offered remote legal services, coordinated a volunteer lawyer program, produced community education events and resources, and offered local, direct legal services of varying scope.

In 2017, in the wake of Hurricane Harvey, the Pepperdine School of Law began efforts to identify ways to help from a distance, serving clients remotely with partner agencies in the disaster's regions. Drawing on personal and professional networks, the clinical faculty identified clinicians and legal aid agencies at work in Houston and reached out with a few initial questions: What help do you need? When will you know what the needs are? How can we help? ${ }^{99}$

Within two or three weeks of Hurricane Harvey, after many conference calls, disruptions, inquiries, and problem solving, Pepperdine

97. Pepperdine Legal Clinics Aid California Fire Victims, PEPPERdne GRAPHIC (Feb. 7, 2018), http://pepperdine-graphic.com/pepperdine-legal-clinicsaid-california-fire-victims/ [https://perma.cc/4TWB-RKKL].

98. A feature in Curbed Los Angeles provides information and insight on Pepperdine's experience in the Woolsey Fire. See Alyssa Walker, Why Pepperdine Stays Put When Wildfires Rage, CuRBEd Los ANGeles (Nov. 20, 2018), https://a.curbed.com/2018/11/20/18097889/wildfire-pepperdine-malibushelter-in-place [https://perma.cc/R9CR-7E45].

99. Jeffrey R. Baker wrote about this experience in a post at the Clinical Law Prof Blog. See Jeffrey R. Baker, Launching a Disaster Relief Clinic (With a Lot of Help), CliniCAL L. Prof BloG (Oct. 22, 2017), https://lawprofessors.typepad.com /clinic_prof/2017/10/launching-a-disaster-relief-clinic-with-a-lot-of-help-.html [https://perma.cc/Y77H-WNJT]. 
established working relationships with Texas RioGrande Legal Aid and Lone Star Legal Aid. Since it was the middle of the semester, the legal clinics organized a pro bono, volunteer program within the School of Law, identifying a pool of volunteer law students who worked under supervision of volunteer clinical faculty to handle referrals from the legal aid partners in Texas. Considering the distance and necessity of handling matters electronically, the clinics and partners settled on a practice limited to FEMA appeals after clients received denials or insufficient awards.

At the beginning of spring 2018, with decanal approval and a teaching release, the clinical program launched the Disaster Relief Clinic, an upper-level elective course satisfying the school's experiential learning and pro bono requirements. ${ }^{100}$ Twelve students enrolled to handle nearly 40 FEMA appeals on referral from Texas RioGrande Legal Aid and Lone Star Legal Aid, integrating into those agencies respective systems for volunteer lawyers. The Texas Supreme Court issued an emergency order permitting foreign lawyers to receive temporary admission to practice on storm-related, pro bono matters, and several of the Pepperdine clinical faculty became short-term Texas lawyers. ${ }^{101}$

The clinic became integrated into the legal aid agencies' referral systems and screened cases that would be appropriate for remote assistance, including clients' access to telephones and the internet for emailing documents and the like. In some cases, the clients would use the legal aid agencies' local offices for signing and document preparation.

The Disaster Relief Clinic soon shifted to serving its own neighbors when the Thomas Fire ravaged neighboring Ventura County, California. Now well-versed in FEMA appeals, the Disaster Relief Clinic partnered with the State Bar of California, local bar associations, local legal aid agencies, and neighboring law schools to stage clinics in the field and to handle FEMA appeals by referral.

The Disaster Relief Clinic, for one semester, did not impose a budgetary impact on the law school. A clinical professor directed the clinic in lieu of teaching another scheduled class. The clinical program integrated the disaster practice into existing systems for case management, communication, client files, and program budgets. The Disaster Relief Clinic was not a sustainable, permanent program, but it created a tested, reliable model for future disasters that will inevitably shake its region.

100. The syllabus is on file and available from the author.

101. See Amended Emergency Order After Hurricane Harvey Permitting Outof-State Lawyers to Practice Texas Law Temporarily, Misc. Docket No. 17-9101 (Tex. Aug. 30, 2017), available at http://www.txcourts.gov/media/1438820/ 179101.pdf [https://perma.cc/NZH2-4HKC]. 
A future disaster arrived on campus on November 9, 2018. On November 9 and 10, the Woolsey Fire burned hundreds of homes in Malibu and burned through Pepperdine's campus. Equipped with the experience of the earlier Disaster Relief Clinic, clinical faculty and administrators agreed to immediately launch the clinic again. The fire, however, displaced faculty, staff, and students from campus for more than two weeks.

To accelerate the provision of legal services to people affected by the fire, the clinical faculty and staff quickly established online forms and a webpage on Pepperdine's website to host materials for the new Disaster Relief Clinic. The website included links and resources on FEMA assistance, insurance, housing, benefits, and legal aid, serving as the Disaster Relief Clinic's first phase of community education. ${ }^{102}$

The Disaster Relief Clinic next built and coordinated an improvised volunteer lawyer program. First, clinic faculty coordinated with the law school's alumni affairs office and personal networks to recruit volunteer lawyers for limited-scope practice. ${ }^{103}$ After the first day of recruiting, nearly 20 lawyers had volunteered; over the next several days, 80 lawyers volunteered to receive pro bono, limited scope clients. Through emails and materials shared on the website, clinic faculty and staff shared training materials and resources with the volunteer lawyers, drawn largely from the previous year's work.

Next, the clinic posted a form online at its website for people to request legal services. ${ }^{104}$ Within six weeks of the fire, the Disaster Relief Clinic

102. The website was temporary, but its material and supporting information are on file and available from the author.

103. The form required this information from volunteer attorneys: name, firm or business, contact information, state of license and bar membership, law license number, and areas of practice. It also required volunteers to answer these questions: How many potential limited-scope or advice-and-counsel clients do you expect that you can take until January 2019? How many potential full-scope clients do you expect you can take until January 2019? Do you agree that all clients you take by referral through the Disaster Relief Clinic will be pro bono for the matters identified through the Clinic? Do you agree to take full, complete, and sole professional responsibility for all clients you take by referral from the Disaster Relief Clinic under your own professional responsibility liability insurance, acknowledging that the Disaster Relief Clinic will not bear professional responsibility for clients and cases you receive by referral?

104. The initial request form prompted clients to provide this information: name, current address, address of the lost home and property, contact information, brief description of the damage suffered, and a brief description of the legal issues or questions. The form also prompted a response to these statements: "I understand that completing this form does not create an attorney-client 
placed over 100 clients with volunteer lawyers through this program. The work included FEMA applications and appeals; advice, counsel, and advocacy on insurance policies and coverage; and self-help and counsel on housing issues for landlords and tenants.

When evacuation orders were lifted, enabling people to return to the community, clinical faculty commenced several community education initiatives. These began with two-hour sessions at local churches to provide orientation and resources on FEMA and insurance matters. Several of the volunteer lawyers joined these sessions to handle individual questions and issues after larger group sessions. These sessions ranged in size from a dozen to sixty people. Clinical faculty participated in other community gatherings, including one on insurance and FEMA issues organized by the local newspaper. ${ }^{105}$ In coordination with local nonprofits and a shopping center, the clinic participated in two weekend events in which nonprofits provided mental health services, post-trauma counseling, yoga, acupuncture, clothing drives, and pro bono legal services. ${ }^{106}$ These events evolved into "sidewalk lawyering" sessions in which clinical faculty and volunteer lawyers addressed questions and provided resources to fire victims who attended the event.

Finally, again in the spring semester, the School of Law launched a provisionally approved, upper-level elective clinical course: the Disaster Relief Clinic. ${ }^{107}$ Eight students enrolled to provide direct legal services to people affected by the Woolsey Fire. Notably, three of those students had also lost their homes or had homes with significant damage. The range of practice included limited scope advice and counsel, FEMA appeals, insurance guidance, and housing guidance. It did not include litigation, but it did include self-help and some ghost-writing for clients. Individual

relationship between me and the Disaster Relief Clinic. Pepperdine University School of Law and the Disaster Relief Clinic are not my lawyers or legal counsel unless I receive and sign a Limited-Scope Engagement Agreement from the Clinic." "I understand that by completing this form I agree that the Disaster Relief Clinic can share my information with volunteer lawyers or partner legal aid agencies." Clinic staff followed up with each potential client with a more detailed intake form that the clinic shared with volunteer lawyers.

105. See Operation Recovery Meeting, Malibu Times (Nov. 26, 2018), $\mathrm{http}: / /$ www.malibutimes.com/operation_recovery/image_c8018864-f1bd-11e8-8 b65-4763a5647565.html [https://perma.cc/BNY3-YJFL].

106. See Barbara Burke, Self-Care at Heart of Day of Malibu Healing \& Assistance, MALIBU SURFSIDE NewS (Dec. 10, 2018, 12:58 PM), https:// www.malibusurfsidenews.com/f/life-arts-living/self-care-heart-day-malibu-heal ing-assistance [https://perma.cc/P9WS-PZL3].

107. The syllabus is on file and available from the author. 
clients came from direct calls to the law school and referrals from partnering legal aid agencies. The work also included some major research and policy projects for the legal aid and nonprofit partners to advance their work and advocacy and to prepare proposals for public policy changes to improve responses to natural disasters.

\section{c. The Effect in the Community}

In its first iteration, the Disaster Relief Clinic handled approximately 40 FEMA appeals for people in Texas after Hurricane Harvey and several more in California after the Thomas Fire.

After the Woolsey Fire, the Disaster Relief Clinic connected over 100 clients to pro bono lawyers in its improvised pool. Clinic faculty presented several community education and "sidewalk lawyering" events with area churches, nonprofits, and newspapers and reached another 200 neighbors with information on FEMA and insurance issues. As of this writing, the Disaster Relief Clinic is underway with students providing direct legal services under supervision to individual clients on limited-scope projects and producing several research and policy projects for partnering nonprofits.

At the close of the 2018-2019 school year, the Malibu Foundation, also founded in response to the Woolsey Fire, provided grant funding to continue the work of the clinic. ${ }^{108}$ In 2019-2020 school year, Pepperdine changed the name of the clinic to Disaster Recovery Clinic and expanded its practice to provide services for rebuilding and permitting and related issues. The Disaster Recovery Clinic continues to serve clients affected by the Woolsey Fire as of this writing.

\section{d. The Outcome}

Pepperdine did not design or implement the Disaster Relief Clinic to be permanent or financially sustainable. It was an improvised response to a great need, and the clinical program hoped to learn and develop models and insights that would be useful in inevitable local events. The only real budgetary impact from the first version was the teaching relief for the primary clinical faculty member who substituted the Disaster Relief Clinic for another course he would have taught.

The second version of the Disaster Relief Clinic relied on faculty who were willing to work an overload without additional compensation. The proximity of the disaster to Pepperdine prompted an outpouring of

108. See MaLIBU Found., https://www.themalibufoundation.org/programs [https://perma.cc/F2PS-RVRX] (last visited Dec. 29, 2019). 
unsolicited donations to the law school from alumni and others. These donations were sufficient for an operating budget to support the clinic's practice and events and to provide limited bonuses to overloaded staff. These systems, experience, expertise, and relationships will be in ready reserve for future wildfires and earthquakes.

\section{e. Lessons Learned}

In the immediate aftermath of a natural disaster - and even as it continues - the urgent needs of survival and safety take precedence. Thus, a remote partner may need to wait until the local attorneys can reassemble their work, take stock of their damage, and triage their tasks before working. Physical needs along with well-intentioned, eager people who want to help right away likely inundate the survivors. Capturing each volunteer's interest and attention is essential, but keeping it and using it usefully is more important and difficult. This lesson occurred at home in 2018 when the Woolsey Fire burned Pepperdine's campus and devastated its neighbors in Malibu.

Volunteer attorneys may also build on this insight, that subject matter expertise is less important than the lawyering process. Especially in an urgent, triaged moment after a disaster, most clients need orientation, direction, and help understanding options. A basic understanding of FEMA programs, standards, and procedures does not require timeintensive, sophisticated expertise, and most lawyers are capable of explaining a lease and insurance policy in essential terms. In the early stages of disaster recovery, lawyers most importantly provide advice and counsel that empowers self-help and clear orientation for a client's next steps. Law students and volunteer lawyers can provide this accessible work in significant volume for affected clients who are trying to find their way. Anecdotally, many lawyers demur from volunteering because they fear assisting clients outside their established areas of expertise, yet they may be very well suited to helping a client bring order and confidence to scattered demands in a crisis.

Next, much of the Disaster Relief Clinic's work and outreach depended on use of the law school's and university's public relations and marketing mechanism and a very active presence on social media. After the Thomas Fire, the clinical faculty realized that much or most of the community's conversations and resources were coalescing in several Facebook groups and Twitter feeds and hashtags. Social media was by far the most efficient and effective way to communicate and promote services and events to the community. These feeds were also essential to 
understanding evolving needs and issues for people displaced and rebuilding after the disasters.

\section{University of Miami School of Law}

The Health Rights Clinic at the University of Miami School of Law offers a great example of the challenges and opportunities that exist for law school clinics even when they prepare for a disaster. Below is an account of its experience in South Florida.

\section{a. The Event}

In September of 2017, following on the heels of Hurricane Harvey, Hurricane Irma-whose field was larger than the state of Texasthreatened the entire state of Florida, causing evacuation chaos in advance of life-threatening destruction. ${ }^{109}$ Simultaneously, on September 4, 2017 , the 17 second-year students enrolled in the University of Miami's Health Rights Clinic were just three weeks into the fall semester. They were beginning to settle into the rhythm of representing real clients and juggling their new and multiple responsibilities. Two students had hearings scheduled for the following week, so class on September 5 had initially been designed to focus on hearing preparation. Instead, it served as a predisaster workshop because, on that day, the University of Miami declared a state of emergency and announced it was closing all operations through at least September 10. ${ }^{110}$ Hurricane Irma, a major category five storm, was headed for south Florida, and officials urged the community to prepare and to evacuate if possible, considering the large city's precarious placement near the bottom of a 500-mile-long peninsula. ${ }^{111}$

The clinic students were understandably concerned for their own safety. Those who did not reside in south Florida began to hurriedly make arrangements to evacuate. Those with family in the Miami area rushed home to assist in their families' hurricane preparations. Despite these important personal needs, because of the vulnerability of the clinic's

109. Irma: A Hurricane for the History Books, CNN, https://www.cnn.com/ specials/hurricane-irma [https://perma.cc/8BWC-7F9W] (last visited Oct. 16, 2019).

110. Storm Alert, U. MiAMI NEwS, https://news.miami.edu/stories/2017/ 09/hurricane-irma-advisory.html [https://perma.cc/66MC-5A3E] (last updated Sept. 15, 2017, 6:30 PM).

111. Greg Allen, Lessons from Hurricane Irma: When to Evacuate and When to Shelter in Place, NPR (June 1, 2018), https://www.npr.org/2018/06/01/615293 318/lessons-from-hurricane-irma-when-to-evacuate-and-when-to-shelter-in-place [https://perma.cc/D8SD-ZKCQ]. 
clients, Health Rights Clinic faculty felt obliged to also make sure that the clinic contacted each of its over 70 clients to review their emergency plans. $^{112}$

As it turned out, Irma affected the entire state of Florida. Approximately 6.5 million residents evacuated the state. ${ }^{113}$ About 6.7 million utility customers lost power as a result of the storm - a crisis that contributed to 123 hurricane-related deaths. ${ }^{114}$ Officials declared 48 of Florida's 67 counties major disaster areas. ${ }^{115}$ The University of Miami's Law School did not reopen until Wednesday, September 20, two full weeks after closing.

\section{b. The Response}

The Health Rights Clinic's response roughly tracked the well-known disaster-management cycle. ${ }^{116}$ The clinic prepared for the disaster, responded to legal needs in the storm's aftermath, and contributed to mitigation in advance of future similar disasters. In preparation, during the evacuation process, each clinic student contacted each of their clients and reported to the clinic staff and directors on their clients' statuses, their own hurricane safety plans, and plans for post-disaster contact. The clinic

112. The Health Rights Clinic represents extremely vulnerable populations who are more at risk during a disaster. Its clients are severely impoverished; many are homeless; over $70 \%$ are immigrants; and most are language or racial minorities. Its clients are also health impaired or living with a disability. See JoNel Newman, Identity and Narrative: Turning Oppression into Client Empowerment in Social Security Disability Cases, 79 ALB. L. Rev. 373, 378-79 (2016); Health Rights Clinic Client Demographic Data, 2006-2017 (on file with author).

113. Meghan Keneally et al., Hurricane Irma: By the Numbers, ABC NEws (Sept. 12, 2017), https://abcnews.go.com/US/hurricane-irma-numbers/story?id= 49677062 [https://perma.cc/8KZT-5KRN].

114. Anindita Issa et al., Deaths Related to Hurricane Irma - Florida, Georgia, and North Carolina, September 4-October 10, 2017, NAT'L CTR. FOR BIOTECHNOLOGY INFO. (Aug. 3, 2018), https://www.ncbi.nlm.nih.gov/pmc/ articles/PMC6072056/ [https://perma.cc/A286-B2MS].

115. United States Dept. Agric., DSNAP approval letter to DCF (Sept. 21, 2017) (on file with author).

116. Wisner et al., Environmental Health in Emergencies and Disasters: A Practical Guide, WORLd Health ORG. (2002), http://www.who.int/iris/ handle/10665/42561 [https://perma.cc/UDH4-FV8H]. 
provided each student and employee with updated contact information and remote file login instructions. ${ }^{17}$

As soon as clinic students returned to Miami on September 20, the clinic tasked them with contacting each of their clients and writing a short memo about how the clients had weathered the storm and what they needed. Every client had lost power and food. Clients who had work-related income had lost at least one week of income. Some had critical housing damages as well. ${ }^{118}$

On September 21, 2017, the United States Department of Agriculture's Food and Nutrition Service approved Florida's Department of Children and Families' request to operate a Disaster Supplemental Nutrition Assistance Program ("D-SNAP") in the 48 counties declared major disaster areas, including Miami-Dade County where the clinic operates. ${ }^{119}$ This program would provide a lifeline to the clinic's client population, who could barely get by without losing food, income, and shelter in a disaster. Although virtually every household in the affected counties had expenditures before and after the storm in safety preparations, clean up, and lost food as a result of electricity outage, the vulnerable clinic clients were least able to bear such losses and additional expenses. The D-SNAP food relief announced by federal and state authorities meant that existing Health Rights Clinic clients could obtain, on average, $\$ 1,000$ for much-needed food. It was clear that assisting clients to obtain this relief was a logical and productive use of the clinic's resources. ${ }^{120}$

117. In anticipation of post-disaster contact, assessment and legal needs, the clinic directors sent students an email describing plans for post-disaster relief, noting:

It seems likely that, even as we rightly worry about our own security in this storm, the client population we serve may be severely affected and in need of even more post-disaster assistance (e.g., emergency Food Stamps, housing, FEMA applications, etc.). We have been so very impressed with your professionalism, concern and dedication to your clients during this difficult time. There may be a marathon of such dedication needed after this storm. But for now, please take care of yourselves and your families, and we hope everyone will be safe and secure.

E-mail from JoNel Newman to Health Rights Clinic students (Sept. 8, 2017) (on file with author).

118. Post-hurricane client memos, Sept. 22-Oct. 5, 2017 (on file with author).

119. United States Dept. Agric., supra note 115.

120. For example, the Department of Children and Families provided the following guidance:

A current four-person household's regular monthly food assistance allotment is $\$ 234$ based on earned income and shelter expenses. The 
D-SNAP eligibility rules are straightforward. D-SNAP entitled individuals and households that received Food Stamps when the hurricane struck to automatic increases of their regular monthly Food Stamp allotment. Low income individuals and households that did not receive Food Stamps were eligible for two full months of maximum benefits. ${ }^{121}$ D-SNAP eased income eligibility restrictions to account for lost work opportunities and did not apply immigration restrictions. ${ }^{122}$

On the clinic's first day back post-hurricane, a group of clinic students did a D-SNAP eligibility training for their peers. Each clinic student then explained D-SNAP to his or her clients. For clinic clients who were already receiving Food Stamps, students simply worked with their clients to ensure that they received the automatic upward adjustment. Clients who were eligible for D-SNAP but had not previously received Food Stamps, on the other hand, were required to make an in-person application. The application process was only open for one week in each of the 48 major disaster counties. Clinic students assisted their clients in this process and uncovered a completely dysfunctional system that was impossible for persons with disabilities to access. Miami's application and distribution sites were swamped. The sites closed early because there were too many people in line. The wait times were in excess of seven hours in public parks with no shelter from the hot sun and rain. Outraged press reports documenting hours of long lines of more than 50,000 people waiting for

maximum allotment for a four-person household in September 2017 is $\$ 649$ and for October 2017 is $\$ 640$. The household will receive a supplement of $\$ 415$ for September and $\$ 406$ for October.

DCF, Food Assistance Supplements for the Disaster Supplemental Nutrition Assistance Program (DSNAP) Due to Hurricane Irma, TRANSMITTAL NO.: I17-09-0014, (Sept. 26, 2017) (on file with DCF). As described above, a typical family of four that already received Food Stamps could get an additional $\$ 821$ to spend on food; we considered this to be an important benefit. Perhaps even more important was the potential for a non-Food Stamp household of four to receive a one-time $\$ 1289$ stipend for food based on the maximum allowance in DCF's policy guidance.

121. Id.

122. See Disaster Supplemental Nutrition Assistance Program (D-SNAP), U.S. DePT. AGRIC. DisASTER AsSISTANCE, https://www.disasterassistance.gov/ get-assistance/forms-of-assistance/5769 [https://perma.cc/M5FJ-TF5J] (last updated July 25, 2018); SNAP Policy on Non-Citizen Eligibility, UNITED STATES DEPT. AGRIC. FOOD \& NUTRITION SERV., https://www.fns.usda.gov/snap/snappolicy-non-citizen-eligibility [https://perma.cc/4XAB-SYQP] (last updated Mar. $24,2018)$. 
food benefits confirmed the situation. ${ }^{123}$ For anyone with a disability, these obstacles were insurmountable.

It quickly became clear that statewide systemic problems prevented thousands of vulnerable households from getting the replacement food they so badly needed. ${ }^{124}$ The intersection between federal and state agency practices and requirements created this problem. In an effort to prevent fraud, the USDA requires an in-person interview for D-SNAP benefits, although it does not require this for receipt of regular Food Stamps. ${ }^{125}$ In some states, or in a smaller disaster area, the requirement may have posed less of a problem than it did in Florida with a disaster the size of Irma.

Florida's Department of Children and Families ("DCF") had embraced electronic benefits administration and qualification processes. As a consequence, the DCF closed all of its local service centers, eliminated the client-caseworker model, and slashed its staff overall by $43 \%{ }^{126}$ The DCF was ill-equipped to manage a food relief effort that required individual in-person interviews when the impacted area was as large and populous as Hurricane Irma necessitated. It simply did not have

123. Monique O. Madan, Food Assistance Centers Close After People Suffer Heat Exhaustion in Line, MiAMI HERALD (Oct. 14, 2017), https://www.miami herald.com/news/local/community/broward/article178932506.html [https://per ma.cc/X7JS-M4VH]; Brian Ballou, Food Voucher Event Cancelled After Heat, Lines Cause Tempers to Flare, Sun SENTINEL (Oct. 14, 2017), https://www.sunsentinel.com/local/broward/fl-reg-food-for-florida-problems-20171014-story.html [https://perma.cc/GQF9-Z2C4]; Glenn Garvin, 50,000 Line Up Outside Tropical Park Seeking Post-Hurricane Food Assistance, Miami Herald (Oct. 15, 2017), https://www.miamiherald.com/news/local/community/miami-dade/article1789963 61.html [https://perma.cc/FCM6-F5R2]; Monique Madan \& Carli Teproff, Why Did Thousands Wait Hours in Hot Sun for Post-Irma Food Stamps?, MiAMI HERALD (Oct. 16, 2017), https://www.miamiherald.com/news/weather/hurricane/article179 220496.html [https://perma.cc/D5T3-XGGL].

124. See, e.g., Kate Santich, Price Tag for Florida Food Relief Program Created After Hurricane Irma Hits \$1.3 Billion, L.A. TIMES (Nov. 5, 2017), https://www.latimes.com/nation/la-na-florida-hurricane-irma-20171105-story.html [https://perma.cc/3AZG-5G8L] (reporting that in Orlando, department officials closed the line at 9:00 a.m.- two hours after it opened-because by 5:00 a.m., 10,000 people were already lined up waiting for assistance).

125. See Skyler Swisher, Hurricane Irma Food Assistance Program Required Long Waits but Little Vetting for Applicants, SUN SENTINEL (Nov. 10, 2017), https://www.sun-sentinel.com/news/florida/fl-reg-food-stamp-fraud-guidelines-2 0171108-story.html [https://perma.cc/Q827-73D8].

126. Scott Cody et al., U.S. Dep't Agric., Modernization of THE FoOd STAMP PROGRAM IN FLORIDA (2008), available at https://fns-prod.azure edge.net/sites/default/files/FloridaModern.pdf [https://perma.cc/7WXM-TAED]. 
the resources to provide the in-person interviews required by USDA that were accessible to persons with disabilities.

The time-limited nature of the program also meant that it was going to close in a matter of days. The clinic reached out to local and statewide advocacy groups and drafted a letter to the DCF that the press later characterized as "scathing," demanding that the DCF extend the distribution of D-SNAP benefits and make accommodations for persons with disabilities. ${ }^{127}$ Although the DCF did not respond in writing, it extended the program for three days in Miami-Dade and Broward Counties but did not provide the requested accommodations for persons with disabilities. In light of the DCF's apparent intransigence on the issue of accommodating persons with disabilities, the Health Rights Clinic began to reluctantly contemplate litigation against both the DCF and USDA.

Many reasons counseled against taking on such a lawsuit, among them that the clinic had just cobbled itself back together from its own evacuation and closing. The clinic already had a full caseload with multiple hearings to reschedule, and federal litigation against two different government entities comes with demanding and often unpredictable deadlines. Further, the failure of the DCF and USDA to devise a D-SNAP program that accommodated persons with disabilities affected 48 counties, not just the southern Miami-Dade County where the clinic practiced. The clinic also questioned whether it was feasible for a Miami-based clinic to prosecute a statewide class action lawsuit.

Some of these questions were resolved by co-counseling with two nonprofit law firms, Florida Legal Services, 500 miles to the north in Tallahassee, and the Community Justice Project, a grassroots and community organizing-focused office in Miami. ${ }^{128}$ Florida Legal Services

127. Letter from JoNel Newman et al. to Jeri Flora-Culley, Assistant Secretary for Economic Self Sufficiency, Department of Children and Family Services (Oct. 17, 2017), https://static1.squarespace.com/static/54179ca4e4b0b0c7bc710d3d/t/ 59f9f82de2c4834a0b80b1e0/1509554222740/DCF+SNAP+Letters.pdf [https:// perma.cc/6PMD-UXH8]; Carli Teproff, DCF, USDA Failed to Accommodate the Disabled for Food Stamp Distribution, Suit Alleges, Miami Herald (Nov. 2, 2017), https://www.miamiherald.com/news/local/community/miami-dade/coralgables/article182429491.html [https://perma.cc/L5ZN-9E95] ("The law clinic and the advocacy groups wrote a scathing letter to the agency demanding several actions be taken to make the distribution equal for everyone.").

128. See FlA. LEGAL SERVS., http://www.floridalegal.org/ [https://perma .cc/CFJ6-WVH6] (last visited Feb. 9, 2019); Community Just. Project, http://communityjusticeproject.com/ [https://perma.cc/2ADP-PRAJ] (last visited Feb. 9, 2019). 
(FLS), although distant and without immediate contact with affected client communities, provided technical expertise on D-SNAP benefits and experienced litigators. The Community Justice Project (CJP) represented two grassroots advocacy organizations that had been active in documenting and protesting the lack of access to D-SNAP. ${ }^{129}$ Advocates would have to seek emergency relief to keep the program from closing in Florida and to secure benefits for clients in any meaningful timeframe.

On November 2, 2017, the clinic, FLS, and CJP filed a putative statewide class action against the DCF and USDA on behalf of two organizational plaintiffs - the Miami Workers Center, a local organization, and the New Florida Majority, a statewide advocacy group based in Miami-and individual clients of the Health Rights Clinic. The clinic filed the complaint along with an Emergency Motion for a Temporary Restraining Order and Preliminary Injunction. ${ }^{130}$ Students who represented clients who had been deprived of D-SNAP benefits due to disability converted their clients' experiences into the factual allegations that went into the complaint and into the declarations that were filed in support of the Emergency Motion for Temporary Restraining Order and Preliminary Injunction.

On November 5, 2017, the court set a hearing for the morning of November 7, ordered the parties to file witness and exhibit lists by 5:00 p.m. on November 6 , and required the parties to confer regarding a provisional remedy in advance of the hearing. The court also ordered the plaintiffs to file Proposed Findings of Fact and Conclusions of Law in support of their request for a Temporary Restraining Order, as well as a proposed Temporary Restraining Order, by 5:00 p.m. on November $6{ }^{131}$ Some clinic students prepared and practiced direct testimony for the TRO hearing with their individual clients. Other clinic students were themselves witnesses to the chaos and inaccessibility of the D-SNAP sites and prepared their own testimonies for the hearing with supervising attorneys. During this flurry of filings, the DCF made a formal request to the USDA to waive its in-person D-SNAP interview requirement to allow telephone interviews for elderly or disabled applicants who had completed a

129. See MIAMI WORKERS CTR., http://www.miamiworkerscenter.org/ [https://perma.cc/5BUE-DWFB] (last visited Feb. 9, 2019).

130. Class Action Complaint for Declaratory and Injunctive Relief, Miami Workers Ctr. v. Carroll, No. 1:17-cv-24047 (S.D. Fla. Nov. 2, 2017) (Doc. 1, 3); see also Teproff, supra note 127.

131. Order, Miami Workers Ctr. v. Carroll, No. 1:17-cv-24047 (S.D. Fla. Nov. 5, 2017) (Doc. 9). 
pre-registration application online. ${ }^{132}$ The focus of the November 7 hearing shifted to the status of the federal and state defendants' accommodations for persons with disabilities, particularly the waiver that the DCF requested. The hearing was continued pending the USDA's consideration of the waiver request, which it granted on November 16. The DCF conducted phone interviews as well as in person interviews for persons with disabilities who had pre-registered for D-SNAP December $2-3,2017^{133}$

These actions resolved the access issue for thousands of persons, including most of the original individual plaintiffs, who were all clients of the clinic. The DCF reported that it had awarded disaster food assistance to more than 4,400 persons through the first-ever telephonic interview process for D-SNAP benefits. ${ }^{134}$ Many members of the putative class, including some clinic clients, however, had not pre-registered. The clinic's clients with disabilities who had not pre-registered continued as named plaintiffs in the litigation, and the organizational plaintiffs worked to identify other persons with disabilities who had been unable to preregister. The litigation continued for several months on behalf of this putative class and went through multiple rounds of motion practice, discovery, and simultaneous settlement discussions. ${ }^{135}$

On May 2, 2018, the parties reached an unprecedented agreement. The DCF identified 158,900 persons with phone numbers who had attempted, but had been unable to, register for D-SNAP. The DCF sent a message to each of those persons, along with the named plaintiffs, stating that if a disability had prevented them from attending a D-SNAP application site,

132. Skyler Swisher, Irma Food-Aid Program to Offer Phone Interviews to Seniors, Disabled, Sun SENTINEL (Nov. 17, 2017), https://www.sun-sentinel.com /news/florida/fl-reg-dsnap-phone-interviews-20171117-story.html [https://perma .cc/UN6D-4TVW]; Wilson Sayre, Qualified Applicants Will Get Phone Interviews for D-SNAP as Suit Continues, WLRN (Nov. 20, 2017), http://www.wlrn.org/post/qualified-applicants-will-get-phone-interviews-d-snap -suit-continues [https://perma.cc/XF29-NFCD]; Catharine Skipp, Health Rights Clinic Lawsuit Allows Thousands to Receive Disaster Food Assistance, MIAMI L. News (Jan. 17, 2018), https://www.law.miami.edu/news/2018/january/health rights-clinic-lawsuit-allows-thousands-receive-disaster-food-assistance [https:// perma.cc/YD8G-PSKW].

133. See sources cited supra note 132.

134. DCF Statistics Report on December 2-3, 2017 calls (Jan. 5, 2018) (on file with author); Law suit Settlement Helps Disabled and Elderly Floridians Re-Apply for Disaster Food Assistance, Community Just. Project (May 4, 2018), http://communityjusticeproject.com/dsnap/ [https://perma.cc/SJ7F-NGXY].

135. Miami Workers Ctr. v. Carroll, No. 1:17-cv-24047 (S.D. Fla. 2017-18) (Docs. 53, 57-59, 62, 70-76, 80). 
they could check their D-SNAP eligibility and apply over the phone. ${ }^{136}$ The group of persons eligible to apply under the settlement agreement included all persons previously identified as having been excluded because of a disability. The agreement provided for accommodations for applicants as well as appeal rights.

\section{c. The Effect in the Community}

The Health Rights Clinic's disaster response efforts post-Hurricane Irma had a significant impact both in the community and on a national policy level. Not only did the clinic ensure that $100 \%$ of its eligible existing clients received the D-SNAP benefits, but the state and federal government agencies extended these benefits to thousands of eligible persons with disabilities. ${ }^{137}$ Several million dollars in food assistance reached some of the state's most vulnerable and isolated persons.

On the policy front, USDA agreed to permit telephone interviews for D-SNAP applicants for the first time ever. As a result of this successful precedent, when Hurricane Michael struck Florida in October 2018, the DCF requested and received permission from USDA to offer telephone interviews to any applicant who had pre-registered online. The DCF also revised its pre-registration form to permit persons to pre-register with identification other than a Florida state-issued ID. Lastly, the DCF set aside an additional weekend solely for phone interviews for persons who are defined as elderly or disabled individuals, those with special needs that prevent them from physically attending a D-SNAP site, and those who care for a household member with a disability.

\section{d. The Outcome}

The clinic's disaster response presented rich teachable moments in the preparation stage. Because the Health Rights Clinic represents extremely vulnerable populations, clinic students know that their own circumstances greatly differ from those of their clients. As Hurricane Irma drew closer to South Florida, the clinic's initial exercise that required students to work on their own safety and evacuation plans while simultaneously reporting on those of their clients, however, concretized students' understanding of the vast gulf between their means to prepare for a disaster and those of their clients. Similarly, the clinic's response illustrated to students how agencies that are sent to help can overlook vulnerable clients and deprive

136. Id. Doc. 82; Settlement Agreement (on file with author).

137. See discussion supra notes 132-36. 
them of even the most basic needs, such as food. But for clinic students having experienced the agencies' failure to accommodate persons with disabilities and bringing it to the attention of other advocates, these injustices would likely have gone unaddressed. The clinic students' experiences made the problem of lack of access to justice for underserved populations clearer to the students than any book or lecture ever could. ${ }^{138}$

The litigation presented an opportunity to expose the clinic to an intense and sophisticated level of practice. Students gained experience and perspective from their interactions with other poverty law advocates, as well as with the U.S. and state attorneys' offices. With the emergent part of litigation resolved in the fall, the clinic spent a substantial portion of its time in the spring semester litigating the case on a more deliberative timeframe. The clinic divided students into two teams. One team worked on discovery and scheduling, and the other worked on briefing. Discovery team students responded to multiple discovery requests, promulgated discovery on defendants, developed a detailed discovery plan, and drafted a proposed scheduling order. Briefing team students responded to motions to dismiss filed by federal and state defendants. The successful outcomes in the case were a source of goodwill for the clinic and the students. Clinic students received an award from the University of Miami School of Law's Public Interest Center for their extraordinary work on the litigation in April 2018. The litigation also provided the clinic itself an opportunity to connect with the larger community and get the message out about its mission.

On the other hand, the clinic sustained significant opportunity costs to undertaking this work, especially, but by no means limited to, the early emergency proceedings. The clinic was essentially in crisis mode for the last month of the already interrupted and shortened fall semester. The clinic had to stop taking in new clients; faculty, staff, and students struggled to triage existing client work. Although the clinic met its professional obligations to existing clients, the faculty had to sacrifice opportunities to engage in structured reflection on these experiences, which are an important pedagogical practice to clinical legal education. ${ }^{139}$

The early emergency time frame also meant that students who represented clients who had been deprived of D-SNAP benefits were

138. See Newman \& Nicolson, supra note 36.

139. See, e.g., Margaret Martin Barry et al., Clinical Education for This Millennium: The Third Wave, 7 CLINICAL L. REV. 1, 17 (2000); Frank Bloch, The Andragogical Basis of Clinical Legal Education, 35 VAND. L. REV. 321 (1982); Kenneth R. Kreiling, Clinical Education and Lawyer Competency: The Process of Learning to Learn from Experience Through Properly Structured Clinical Supervision, 40 MD. L. REV. 284 (1981). 
incredibly busy converting their clients' experiences into the factual allegations that went into the complaint, declarations, and later testimony. There simply was not enough time to use student work product in other aspects of the emergency filing. The bulk of the complaint, emergency motion and brief were divided among the lawyers. This is an anathema to the Health Rights Clinic's typical ethos.

\section{e. Lessons Learned}

Students were very anxious about their personal safety as Hurricane Irma approached. The University of Miami contributed to students' anxiety by announcing its closure quite early. Additionally, for students unfamiliar with hurricanes in particular, the clinic's request that they work with clients and take some of their client issues with them as they evacuated struck them as insensitive. Looking forward, mitigation of this issue will involve teaching the ABA's ethics guidelines on disaster preparation early on so that students are better inculcated on this important aspect of professionalism and know what to expect. ${ }^{140}$ Moreover, the clinic's offices were completely inaccessible for more than two weeks; widespread electrical outages lasted even longer. This experience re-emphasized the importance of maintaining redundant files and contact information for students, clients, and office staff.

The intense, sophisticated, and rapid litigation response was only possible because of the clinic director's prior experience with similar federal litigation and the clinic's partnering with two other law offices. At the time the clinic agreed to initiate the case and co-counsel, however, it underestimated the impact that years of severe funding shortages for other Florida legal services providers would have on their capacity to contribute to the litigation. ${ }^{141}$ The partnership was extremely beneficial, but the parties experienced tensions with respect to availability, division of workload, and resources from the beginning. As the case progressed, other tensions and disagreements arose from differing goals in the settlement

140. See ABA Comm. on Ethics and Prof'1 Responsibility, supra note 19.

141. The recession that began in 2010 resulted in Florida losing more than 100 legal aid lawyers and basic infrastructure due to funding cuts and low interest rates on lawyer trust accounts. The IOLTA program on which Florida depends fell from an income of $\$ 70$ million annually to $\$ 5.5$ million in 2013. See Anna M. Phillips, Florida's Legal Aid Services for the Poor Imperiled by Budget Cuts, TAMPA BAY TIMES (Sept. 6, 2014), https://www.tampabay.com/news/courts/floridas-legalaid-services-for-the-poor-imperiled-by-budget-cuts/2196497 [https://perma.cc/Q MC2-23ZZ]. 
phase. In retrospect, the project would have benefited from more conversation about all of these issues at the outset.

\section{Touro College Jacob D. Fuchsberg Law Center}

Touro College Jacob D. Fuchsberg Law Center began its engagement with disaster relief by engaging with the Student Hurricane Network after Hurricane Katrina. ${ }^{142}$ That involvement in post-disaster relief efforts in New Orleans began to build relationships that proved most useful to respond when a natural disaster hit home. ${ }^{143}$

\section{a. The Event}

Superstorm Sandy claimed the lives of approximately 147 individuals in October 2012 as it passed through the Caribbean, Canada, and the Northeastern United States. ${ }^{144}$ It is estimated that Sandy caused $\$ 62$ million in damages. ${ }^{145}$ Sandy overwhelmingly flooded New York from the storm surge and extreme rainfall. Storm waters inundated homes and neighborhoods, urban infrastructure, and transportation facilities. ${ }^{146}$

\section{b. The Response}

Touro College Jacob D. Fuchsberg Law Center ("Touro Law") mobilized to provide a response to Superstorm Sandy. A few days after the storm, Touro Law collaborated with the Suffolk County Bar Association, a disaster relief center, and the student-based Student Hurricane Network, launching the Hurricane Emergency Assistance and

142. Telephone interview with Thomas Maligno on January 23, 2019.

143. Id.

144. Sandy is referenced as a superstorm, a hurricane, and a cyclone. Regardless of what it is called, Sandy was an extremely destructive and costly natural disaster. See Hurricane Sandy Fast Facts, CNN, https://www.cnn.com /2013/07/13/world/americas/hurricane-sandy-fast-facts/index.html [https://perma .cc/T83Q-3Q76] (last updated 3:34 PM, Oct. 29, 2018).

145. See Adam Jeffrey, Five Years on: A Look Back at the Destruction Caused by Superstorm Sandy, CNBC (Oct. 30, 2017), https://www.cnbc.com/2017/10/ 30/five-years-on-a-look-back-at-the-destruction-caused-by-superstorm-sandy.html [https://perma.cc/73KR-5LBH].

146. See generally Jeff Tollefson, New York vs The Sea, 494 NATURE 162 (2013); Jacob William Faber, Superstorm Sandy and the Demographics of Flood Risk in New York City, 43 HuMAN ECOLOGY 363 (2015) (addressing the disaster's intersection with social factors, such as race, poverty, and age). 
Referral Team ("HEART") hotline. ${ }^{47}$ The HEART hotline immediately provided victims of Sandy with "referrals, assistance, and legal advice for local residents and small businesses." 148 It later became a clinic at Touro Law that focused on disaster relief. At the time, the clinic was the first of its kind.

The Disaster Relief Clinic assisted area households on a variety of legal issues that included: insurance underpayments and coverage denials; contractor disputes; and FEMA recoupments and the FEMA Sandy Claims Review Process. ${ }^{149}$ The clinic also worked with clients to claim the appropriate state benefits and worked with policymakers to effectuate disaster-related reform that benefitted victims. ${ }^{150}$ In its work, the clinic engaged not only its own students but also students from other law schools. ${ }^{151}$ Because it had developed expertise in navigating disaster-related legal issues, the clinic began offering support to disaster victims and recovery efforts in other parts of the country. ${ }^{152}$ The clinic director also became a consultant for FEMA and, in that role, recently met with clinic directors and bar leaders in Texas to help them think about how to respond to Hurricane Harvey. ${ }^{153}$

\section{c. The Effect in the Community}

The Touro Law Disaster Relief Clinic reached more than 5,000 households and represented about one-third of those households ${ }^{154} \mathrm{It}$ reported that it helped disaster victims recover over $\$ 4$ million in flood insurance, FEMA assistance, and state benefits. Although the disaster occurred years ago, the clinic reported at least 125 active cases and continuous requests for assistance as late as January 2019. ${ }^{155}$ Touro Law

147. Touro Law Center's Disaster Relief Clinic, TOURO L., https://www.tourolaw.edu/TLCHEART/?pageid=1079 [https://perma.cc/DJ23-MP 7K] (last visited Oct. 16, 2019).

148. Id.

149. Id.

150. Telephone interview with Thomas Maligno, supra note 142.

151. Id.

152. Id.

153. Id. According to Thomas Maligno, the conference in Houston, held in the summer of 2018, had approximately 50 participants and focused on helping local advocates connect with government officials who dealt with flood insurance claims through FEMA.

154. Touro Law Center's Disaster Relief Clinic, supra note 147.

155. Id. 
developed a Disaster Relief Manual that documented its contributions, lessons learned, and best practices. ${ }^{156}$

\section{d. The Outcomes for the Clinic}

The Disaster Relief Clinic at Touro Law was quite successful in meeting the disaster-related legal needs of the local community, but after approximately six years of service, it closed its doors in December 2018 due to insufficient funding. ${ }^{157}$ Although the clinic still receives calls related to legal problems that arose as a result of Superstorm Sandy, it no longer takes new clients. ${ }^{158} \mathrm{~A}$ local community partner funded an attorney to close out its $25-30$ remaining cases. ${ }^{159}$ When discussing the work that the Disaster Relief Clinic did, its last director, Thomas Maligno, attributes much of the clinic's success to the relationships the faculty developed in the community with other community service providers, including social service agencies, nonprofits, and governmental organizations. ${ }^{160}$

\section{e. Lessons Learned}

Before the Disaster Relief Clinic closed its doors, it held a day-long conference to reflect on lessons learned that could help provide a roadmap for the future. ${ }^{161}$ The conference, hosted by Touro Law and the Health and Wellness Council in Long Island, convened government officials, community groups, and legal services providers. Maligno reported that "one of the chief recommendations [from the conference] was that there needs to be more long-term, stable sources of funding for disaster work." $\mathrm{He}$ and other conference attendees planned to continue to advocate for

156. Melissa H. Luckman \& Patricia R. Sturm, Restoring Power: How a Law School Responded to Superstorm Sandy, 2 TOURO L. J. EXPERIENTIAL LEARNING 232, 234 (2018).

157. Telephone interview with Thomas Maligno, supra note 142.

158. Id.

159. Id. According to Maligno, the local United Way chapter funds the attorney on a per diem basis.

160. Id. Maligno specifically credits the relationship with the local Volunteer Organizations Active in Disaster (VOAD) contact for their ability to engage with others to properly respond to local needs. Id. The National VOAD is an association of organizations that helps to coordinate services after a disaster. The National VOAD is comprised of more than 100 national, regional, and state nongovernmental organizations. See NAT'L ASS'N OF VOLUNTARY ORGS. ACTIVE IN DISASTERS, https://www.nvoad.org [https://perma.cc/J6YL-HN6X] (last visited Aug. 15, 2019).

161. Telephone interview with Thomas Maligno, supra note 142. 
more sustained preparedness efforts with local and regional government entities who have the capacity and can generate the resources for more long-term solutions, since disaster-related legal issues often do not resolve in one or two years.

\section{Stetson University College of Law}

At Stetson University College of Law, pro bono efforts to support the bar's engagement in disaster relief provided students with great experiences and the law school with improved community relations. Details of their project follow.

\section{a. The Event}

Hurricane Irma was "one of the strongest and costliest hurricanes on record in the Atlantic basin."162 The storm switched course several times and at one point threatened the entire state, causing massive evacuations. This uncertainty provoked anxiety and disrupted the regular course of business operations throughout the state. Stetson University's campus on the Florida west coast was under threat and planned for direct impact, which caused the administration to evacuate the entire campus. Ultimately, the campus went without power for five days and suffered minor damage, mostly from high winds. Although the west coast of Florida returned to normal relatively quickly, the southern and eastern coasts struggled to regroup and rebuild after Irma's impact.

\section{b. The Response}

Although Tampa and Gulfport did not suffer grave damage, Stetson mobilized to assist neighboring regions in Florida and to teach law students through disaster relief. In December 2017, Stetson launched the "Disaster Research Project" ("DRP"). The DRP is an online research portal designed to assist pro bono attorneys with research questions related to disaster benefits by connecting law student researchers to legal research projects. ${ }^{163}$

162. John P. Cangialosi et al., Nat'l Hurricane Ctr., Hurricane Irma 15 (June 2018) (available at https://www.nhc.noaa.gov/data/tcr/AL112017 Irma.pdf [https://perma.cc/Z82X-BQJR].

163. See Shannon Edgar, The Official Launch of Stetson's Disaster Research Project, STETSON L. (Nov. 3, 2017), https://www.stetson.edu/law/docket/the-off icial-launch-of-stetsons-disaster-research-project/ [https://perma.cc/GYS3-2BYG]; Stetson Launches Project Working with Disaster Relief Hotline Attorneys to Assist 
The idea for the DRP stemmed from a suggestion during a weekly disaster phone call that the ABA Young Lawyers Division led in the aftermath of the storm. During these weekly phone calls, those with firsthand knowledge in the field provided information directly to those seeking ways to serve. Stetson identified a need for research assistance for volunteer attorneys responding to clients through the disaster hotline. Many of the volunteer attorneys had never practiced in disaster law or understood FEMA benefits, and Stetson students could expand the lawyers' capacity by assisting with discrete research questions.

The DRP required university departments to collaborate to create an online portal for attorneys to submit their research questions and then to connect students as researchers. The law school personnel engaged in information technology, web design, communications, marketing, and building management to help shape the idea into a working project. The web team designed two online forms, one for attorneys to submit questions and one for students to sign up, which linked to the supervising professor's calendar. Once an attorney submitted a research question, the professor could access the question and organize the assignment through a shared drive. The professor required an initial meeting with each assigned student to explain disaster benefits and the nature of the project. Students received training materials with an overview of FEMA and disaster benefits, FEMA's individual household manual, and Florida's disaster manual. ${ }^{164}$ Each student could choose a particular research issue, and organizers encouraged them to complete the assignment within a short period of time. Students would meet with the professor to review the findings and discuss the research in more detail. Several students could research one issue to provide a comprehensive overview, and the professor would merge the research into one or multiple files to submit to the attorney, acknowledging every student for their contributions in the final memorandum, which provided a great moment of pride for many of the students.

Victims of Weather Disasters, STETSON L. (Dec. 6, 2017), https://www.stetson .edu/law/news/index.php/2017/12/04/stetson-launches-project-working-disasterrelief-hotline-attorneys-assist-victims-weather-disasters/ (describing Stetson students as helping with relief effort).

164. Public Assistance Program and Policy Guide (PAPPG), FEMA, https:// www.fema.gov/media-library/assets/documents/111781 [https://perma.cc/RU4JTD64] (last updated Feb. 7, 2019); Individuals, Households Program Unified Guidance Final (IHPUG), FEMA, https://www.fema.gov/media-library/assets /documents/124228 [https://perma.cc/C9NH-3KMW] (last updated Jan. 5, 2017); Florida Disaster Assistance Manual for Legal Service Advocates, FLA. LEGAL SERVS. INC. (June 2014), https://flayld.org/wp-content/uploads/2016/11/ Disaster070214Manual.pdf [https://perma.cc/6L4Z-RLXX]. 


\section{c. The Effect in the Community}

The DRP enabled Stetson and its students to join the ranks of volunteer pro bono lawyers by providing helpful resources to these lawyers. The DRP was a simple project with important benefits. Practically, the project generated a database of cataloged research to build a library for future disasters. Also, students could fulfill pro bono hours necessary to graduate and could better understand the importance of building skills in an area of pro bono practice that directly served the community. ${ }^{165}$ Overall, the project first launched and completed eight total research projects with six students. The second launch produced two projects and one long-term publishable piece with 17 students involved in the research.

Although the effect of the project in the community is difficult to quantify, the DRP hopes to inspire more attorneys to engage in pro bono work. This type of project assists volunteer attorneys by providing support in learning new areas of law. The project also inspires the next generation of attorneys to learn about disaster law. Anthony Palermo, the attorney who helped coordinate the efforts of the Florida Bar Young Lawyers Division and the ABA Young Lawyers Division, recognized that the project provided rewards for both students and lawyers in the community. ${ }^{166}$ The organizers of the DRP may not understand the long-

165. The effect in the immediate student community showcased that students were engaged in disaster work, as many students signed up multiple times. See quote from law student Timothy $\mathrm{E}$. Wieneke, who volunteered three times: "Before I came to Stetson, I worked in disaster zones and [had] first hand experience with how devastating disasters are to good people. This is a great project where you can know you're helping good people rebuild their lives." The effect in the legal community is relatively unknown, other than feedback from the attorneys (quote from attorney, David Naples who submitted a research question and sent a message to the students: "Thank you so much for your assistance. This is such a valuable service that you are providing to those less fortunate and you should be extremely proud to be a part of this.....Thank you!!!"). Note on file with authors.

166. See Anthony J. Palermo, Lessons Learned in Providing Disaster Legal Services in Florida, L. PRAC. TODAY (Dec. 14, 2017), https://www.lawpracticeto day.org/article/lessons-learned-providing-disaster-legal-services-florida/ [https:// perma.cc/KRN6-VZAY], stating:

Through this project, Stetson law students conduct legal research for attorneys helping disaster survivors through the hotline. Law students not only aid the relief efforts, build relationships with current practitioners, and ensure that more people get the help they need, their research assistance also enable volunteer attorneys to take on more cases without getting overburdened while balancing other client demands. This 
term benefit for several years, but hopefully the DRP will address future disaster needs and inspire students to become active leaders in the profession. Such an experience can create a comfort level for these students to volunteer as pro bono attorneys to address future disaster work.

\section{d. The Outcome}

Hurricane Michael impacted the Florida panhandle in 2018 and prompted a relaunch of the DRP over the 2018 winter break. Again, participation in the weekly disaster phone calls allowed the school to engage with the community and understand its needs. This time, the collateral benefit for the relaunch was to engage and motivate the law school's alumni to volunteer and take pro bono cases. Hurricane Michael required more volunteers in the response efforts to support fatigued legal aid offices in north Florida.

One improvement was a request to address systemic issues, such as landlord and tenant rights post-disaster that were governed by state statute, and to create a handbook ready for the next event. Students engaged in this project through the academic year. The project created momentum on campus that enabled discussion about more formal curricular offerings to address disaster related needs. As a result, a Disaster Law Practicum course was offered in spring 2020.

In the summer of 2019, the curriculum committee approved the Disaster Law Primer and Externship that are offered as separate one-credit courses. Students are able to enroll in the Disaster Law Primer co-taught by Professor Linda Anderson Stanley, the Senior Project Manager for Public Programs at Equal Justice Works and leader of the Disaster Recovery Legal Corps, and also Professor Christine Cerniglia, Director of Clinical and Experiential Education.

The one-credit primer is designed for students to understand disaster law and to prepare to handle a FEMA appeal. The Disaster externship course is designed for students to work directly with the Disaster Recovery Legal Corps, specifically to assist with FEMA appeals. The externs engage in experiential learning by providing direct assistance for those impacted

encourages additional attorneys to get involved as they have the confidence of knowing that they have support to keep them from becoming inundated by volunteering on top of their already busy practices. The project undoubtedly presents a rewarding experience for the lawyers and students involved in addition to helping to keep the hardworking attorneys at Florida's legal aid organizations from receiving too great an influx of disaster legal work and helping to ensure that Floridians get the help they need. 
by a disaster. Both courses were offered for the first time at Stetson College of Law in the spring of 2020.

\section{e. Lessons Learned}

The most important lesson learned from Stetson's DRP experience is that the best first response is to listen, wait, and learn more about the needs in the community before launching a project. The next responsible step is to determine whether resources and ability align to serve the call. The second important lesson is to commit to collaboratively work with partners like the State Bar Young Lawyers Division and the ABA Young Lawyers Division and to attend the conference calls to organize disaster responses. The conference calls allow law schools to hear from practitioners in the trenches to better understand the need in a specific community and connect with a network with immediate ability to reach out to a director of a legal aid organization.

Ethical issues are important to address before launching such a project, specifically confidentiality, potential conflicts of interest, and the scope of the attorney-client relationship. The DRP carefully confirmed that the ultimate responsibility for representation remained with the attorney. Under Florida ethics rules, short-term limited legal services, such as advice clinics or hotlines, are permitted, and although it establishes a client relationship, clients have "no expectation that the lawyer's representation of the client will continue beyond the limited consultation."167 The ethics rules address a structure to provide direct legal services, rather than indirect services as the DRP envisioned that assist volunteer attorneys in their roles. Out of precaution, the directing professor sought guidance from the state bar ethics hotline, which provided support and unofficial endorsement of the altruistic goals for the project. The professor ensured that the clinic addressed all potential ethical issues before assigning work to the students or returning assignments to the attorneys.

Recognizing the importance for law schools to engage in disaster outreach is also important to teach the principles necessary for the future generation of lawyers to advocate where others are unable. Often, an idea for outreach is met with resistance, over-analysis, or focus on challenges. Many lawyers may feel stymied by this negativity and may ultimately abandon an idea for outreach. Designing a program to engage law students in future pro bono work while empowering reluctant lawyers to embrace

167. See Fla. Rules of PROF'L CONDUCT r. 4-6.6 and corresponding comment (stating that conflict checks are not feasible when providing short-term legal services and are therefore not applicable unless an attorney becomes aware of a specific conflict). 
the immediate needs in the community, however, is rewarding. The support from the law school's administration is especially beneficial, and the commitment by one professor to oversee the project is critical. Ultimately, the project inspired university departments and created momentum and energy toward more collaboration.

\section{Texas A\&M University School of Law}

Not all schools will be ready to jump into action. Texas A\&M University School of Law, for example, was newly formed and still developing its infrastructure when disaster hit its state. In this section, we discuss some limitations that may hinder law schools from participating in post-disaster efforts.

\section{a. The Event}

Not all good faith attempts by law schools lead to direct service assistance. When Hurricane Harvey struck the Gulf Coast in August 2017 , Texas A\&M University School of Law ("TAMU Law") students from Houston had begun to arrive in anticipation of classes starting. Hurricane Harvey was responsible for the deaths of 107 individuals and was the most expensive tropical cyclone in modern history with an ongoing price tag of over $\$ 125$ billion. ${ }^{168}$

In the days before Harvey hit, the TAMU Law students scrambled to ensure that their families either evacuated or returned home to properly prepare for the storm. Given the timing of the semester and the law school's location in Fort Worth, the law school and the majority of its students were not impacted by the storm. ${ }^{169}$ However, most students, faculty, and staff had friends and family who were impacted and were eager to assist. ${ }^{170}$

168. Hurricane Costs, OFF. FOR COASTAL MGMT., https://coast.noaa.gov/ states/fast-facts/hurricane-costs.html [https://perma.cc/36F9-53WQ] (last visited Aug. 15, 2019).

169. The Texas A\&M School of Law is located in Fort Worth, Texas, which is approximately four hours, or 260 miles, from Houston, Texas.

170. Although TAMU Law was not directly involved in the hurricane, the university reported that 31,000 , or $45 \%$, of its student body originated from one of the counties impacted by Hurricane Harvey. See Letter from Michael K. Young, President, Tex. A\&M (Sept. 8, 2017). 


\section{b. The Response}

Although students, faculty, and staff showed sufficient interest in responding to Hurricane Harvey, TAMU Law was not substantially engaged in post-disaster recovery efforts that involved legal assistance or research. The lack of engagement was not due to lack of interest, but it did signal that the school, which was just beginning its fourth year, did not have mature relationships with the bar associations and the legal aid organizations coordinating the disaster relief efforts. ${ }^{171}$ These associations often either did not return calls to offer assistance or redirected them, in part because TAMU Law was a new player, but also because some of the key legal aid attorneys and bar leaders were overwhelmed with offers to help.

Organizers answered initial calls to offer assistance with requests to wait for further instruction. A fire at Lone Star Legal Aid's offices in Houston posed part of the problem, so the priority became relocating the legal team to other offices to address the immediate needs of the population they served. ${ }^{172}$ Local law firms immediately responded by offering office space to legal aid lawyers and also additional pro bono assistance. ${ }^{173}$ The next set of calls indicated that individuals would be traveling to shelters in the Dallas and Fort Worth Metroplex and that TAMU Law would receive calls to assist when they arrived. Responders set up several shelters in the area, but the calls to help provide legal services in those shelters did not materialize. ${ }^{174}$ Many of the evacuees

171. At the time, TAMU Law was in its fourth year of existence. Texas A\&M University purchased Texas Wesleyan University School of Law in 2013 and began operating as Texas A\&M University School of Law during the 2014-15 school year. See Our History, TEXAS A\&M, http://www.law.tamu.edu/aboutus/our-history [https://perma.cc/NFA4-YL6N] (last visited Aug. 15, 2019).

172. See Weiss, supra note 72.

173. See Brenda Sapino Jeffreys, Firms Provide Displaced Legal Aid Agency with Office Space in Houston, TEX. LAw. (Nov. 10, 2017, 4:21 PM), https://www. law.com/texaslawyer/sites/texaslawyer/2017/11/10/firms-provide-displaced-legalaid-agency-with-office-space-in-houston/?slreturn=20190026011417 [https://perm a.cc/JTB6-D8RH].

174. See Dallas Opens Two Shelters to Help Hurricane Evacuees, NBC 5 (Aug. 25, 2017), https://www.nbcdfw.com/news/local/How-North-Texans-CanHelp-Hurricane-Harvey-Evacuees-441768543.html [https://perma.cc/X5GS-FT8 8] (reporting two shelters in Dallas); Todd Unger, Hurricane Harvey Evacuee: 'This Is Home for Us Now' After Fort Worth Stepped Up to Help, WFAA (Aug. 30, 2018, 4:06 PM), https://www.wfaa.com/article/news/hurricane-harvey-evacu ee-this-is-home-for-us-now-after-fort-worth-stepped-up-to-help/287-589107448 
returned to their homes along the Gulf Coast, and those who remained presumably received pro bono assistance organized through the Dallas Bar Association or the Legal Aid of Northwest Texas.

\section{c. The Effect in the Community}

Legal aid and the private bar have handled much of the pro bono legal assistance related to Harvey. The private bar extended involvement to attorneys licensed outside of Texas through a Texas Supreme Court order that allowed for out-of-state attorneys in good standing to provide pro bono assistance to disaster victims. ${ }^{175}$ FEMA also does not require attorneys to handle claims, so out-of-state volunteers could assist with greater volume. Out-of-state attorneys and advocates with experience working with FEMA seemed to get calls to assist before TAMU Law. When TAMU Law finally received a call to help, organizers requested help in addressing the needs of the vulnerable populations that existing pro bono efforts could not reach, including undocumented immigrants. The request turned out to be politically and practically unfeasible to execute because it required a bar partner, new clinic staff, or a well-resourced pro bono program. TAMU Law's existing infrastructure and the culture of the Tarrant County Bar Association were not amenable to accommodating the request.

\section{d. The Outcome}

Several months after Hurricane Harvey, a group of TAMU Law faculty organized a conference on Disaster Recovery. ${ }^{176}$ Academics, lawyers, judges, government officials, policymakers, and community leaders convened to discuss "the importance of a long-term commitment to rebuilding and repairing not only the physical but also the social structure of communities affected by these events." 177 In August 2017,

[https://perma.cc/M7QU-5Y25] (reporting a shelter and hospital that served to shelter babies and children in Fort Worth).

175. See Lowell Brown, UPDATE: Texas Supreme Court Adds, Amends Harvey-Related Orders, ST. B. TEX. (Feb. 26, 2018), https://blog.texasbar.com/ 2018/02/articles/news/texas-supreme-court-adds-amends-harvey-related-orders/ [https://perma.cc/56BM-XCTV].

176. See Tyra Kelly, ADR Program Hosts Disaster Recovery Conference, TEX. A\&M U. SCH. L. (Apr. 27, 2018), https://law.tamu.edu/media/news-mediaresources/story/adr-program-hosts-disaster-recovery-conference [https://perma.c c/58EJ-E9Z9].

177. Id. (quoting Charlotte $\mathrm{Ku}$ ). 
Texas Governor Greg Abbott created the Governor's Commission to Rebuild Texas-a multi-agency effort headed by the Texas A\&M University System Vice Chancellor and Chief Financial Officer. ${ }^{178}$ The Commission to Rebuild Texas issued its report in December 2018. The report documented the response effort between state and local governments to ensure that they minimized the community impact of the disaster. ${ }^{179}$ Clinicians need to develop similar reports for coordination between bar associations, legal aid, the private bar, and law schools to deliver legal services in each community.

\section{e. Lessons Learned}

TAMU Law, although willing and interested, did not launch a post-disaster initiative as a unique result of its young age and early stage of development. Many law schools face the same obstacles with overworked clinical faculty and attorneys. They do not have sufficient infrastructure for the proper malpractice insurance in their pro bono programs. They do not have the required relationships with local bar leaders or legal aid providers around disaster relief efforts.

Regardless of the resources available, law schools should play a role in the legal service delivery system that follows a natural disaster. A law school's response can involve their clinics and pro bono programs, but it can also involve career services offices and non-clinic faculty who can supervise research or advise lawyers in the jurisdiction about pertinent law.

\section{B. Paths Not Yet Taken: Potential Future Responses}

The law schools' experiences demonstrate several options for clinical responses to natural disasters. These include remote practices with partner agencies, specialized clinics focused on recovery resources, integrated practices that adapt to existing clients' needs, limited-scope clinics, impact litigation, and auxiliary support for pro bono lawyers. These options are

178. Id.

179. See John Sharp, Rebuild TeXas, Eye of the Storm (Nov. 2018), available at https://gov.texas.gov/uploads/files/press/RebuildTexasHurricaneHar veyEyeOfTheStorm_12132018.pdf [https://perma.cc/5LQF-GTRL]; Kenny Wiley, Commission Led by Sharp Calls for Infrastructure Improvements After Hurricane Harvey, EAGLE (Dec. 13, 2018), https://www.theeagle.com/news/a_m/ commission-led-by-sharp-calls-for-infrastructure-improvements-after-hurricane/ article_d530488e-ff02-11e8-9aee-1369f27ccf5f.html [https://perma.cc/6697-KG PK]. 
not exhaustive possibilities. Below are several ideas for law schools and clinical programs to fill unmet needs, to leverage law professors' expertise, to engage externship programs, and to capitalize on pro bono networks. $^{180}$

\section{Legislative Advocacy}

Law schools and legal clinics far removed from active natural disasters could consider engaging in legislative policy and advocacy work with partners in the field or enacting preparedness legislation in their own jurisdictions. During and after a natural disaster, legal aid agencies, nonprofits, and law schools in direct proximity likely will not have the capacity or cognitive energy to engage in critical policy work while they work for survival and rebuilding. Law schools and clinics not in disaster chaos, however, can use their processes and creativity to improve the law and public responses to disasters. Proactive legislation to ensure public social services and disaster assistance helps stabilize the community. ${ }^{181}$

Jurisdictions that have enacted legislation after a disaster provide progressive ideas for best responses. Law school outreach with an eye on legislative preparedness is an important advocacy role, especially when other disaster outreach players are unable to advocate. Students may help the legislative process by collecting data specifically to understand the need for such legislation. They can describe how the proposed policy may serve a specific community and end result. For example, legislation prohibits legal aid offices funded by LSC from lobbying efforts, and the ABA Young Lawyers Division or state bar associations may be barred from vocalizing concerns against FEMA because of established memoranda of understanding. State law schools or state entities are

180. Cf. Gary Bellow \& Jeanne Charn, Paths Not Yet Taken: Some Comments on Feldman's Critique of Legal Services Practice, 83 GEO. L.J. 1633 (1995) (describing future possibilities for legal services).

181. A.B. 607, 2017-2018 Reg. Sess. (Cal. 2017) (Public Social Services: Disaster Assistance Services); H.R. 32, 29th Leg. (Haw. 2018) (Requesting the State to Include in Its List of First Responders a Network of Organizations Contracted to Immediately Provide Food, Beverages, and Ice to Citizens During a Natural Disaster); H.R. 4930, 115th Cong. (2d Sess. 2018) ("This bill amends the Robert T. Stafford Disaster Relief and Emergency Assistance Act to prohibit the President from considering the income of an individual or household in determining whether to provide, or continue to provide, rental assistance under provisions pertaining to federal assistance to individuals and households in states affected by a major disaster."); see also New Jersey, A.B. 333, 2016-2017 Reg. Sess. (N.J. 2017) (protecting homeowners from foreclosures happening while persons are financially still recovering from the storm). 
sometimes hesitant to file litigation against the state or agency officials due to internal tension. Legislative policy work allows other law schools to create an outreach effort in the clinical space to help propose and lobby legislation to address better responses on systemic issues.

A legislative clinic may initiate coursework to teach students the process and roles in the legislative process. ${ }^{182}$ The course may engage students through exploration with structured readings on specific issues in disaster response to identify a need within a particular jurisdiction. Students may study legislation within the jurisdiction and also compare jurisdictions to find gaps or needs to address disaster preparedness. Jurisdictions that have endured the chaos of disaster likely have legislation that other states can use to model and propose where gaps exist in their states. Such model legislation may help to protect certain populations throughout the nation. Essentially, the students would become legislative lawyers to help assess the problem, research, and propose a solution. Some law clinics have actively engaged in legislative lawyering to assist with property title issues before a disaster strikes. ${ }^{183}$ Legislative advocacy and outreach provide assistance in different formats to hopefully implement systemic policy changes.

\section{Externships}

Externship placements and courses may also offer an opportunity to design a law school's curricular response after a disaster. Many externship directors are familiar and have working relationships with field placement supervisors who provide direct legal services. After a disaster, such placements are directly impacted, and an externship program that is nimble to respond to disaster needs allows eager students to engage in the response while also increasing the capacity of the field office. The

182. Chai Rachel Feldblum, The Art of Legislative Lawyering and the Six Circles Theory of Advocacy, 34 MCGEORGE L. REV. 785, 786 (2003).

183. Id. at 818-19. Other active outreach efforts include law clinics who help ensure property is properly recorded, sometimes known as "heirship clinics." U.S. DEPT. AGRIC., HeIRS' Property AND LANd Fractionation: Fostering STABle OWNERSHIP TO PREVENT LAND LOSS AND ABANDONMENT (Cassandra Johnson Gaither et al. eds., 2019), https://www.srs.fs.usda.gov/pubs/gtr/gtr_srs244.pdf [https://perma.cc/MZU3-HZPN]; see Heirs' Property Retention Coalition, HPRC PROJECTS, https://hprc.southerncoalition.org/?q=node/3 [https://perma.cc/C4LM -MN6P]; see also Christy Kane, Letters: Lack of Clear Titles to Inherited Property Is Still a Problem After Hurricane Katrina, AdvoCATE (Aug. 20, 2015), https://www.theadvocate.com/baton_rouge/opinion/letters/article_65bd246fb9f4525a-b009-387d051acab2.html [https://perma.cc/Z6KA-FLEN]. 
important responsibility of a law school is to prepare and train students before or during the externship to understand disaster response and to not place an additional burden on the field office to adequately train.

An externship professor may want to assign course readings to ensure students understand government function, the role of legal aid offices, and how lawyers assist in the community to ensure civil liberties and adherence to constitutional procedure. ${ }^{184}$ Externs may participate in online training provided by FEMA or learn with pro bono attorneys post-disaster to ensure they understand how to conduct intake or to study the systemic issues relevant after a disaster. ${ }^{185}$ Externs experience firsthand how legal service providers organize efforts to respond with direct outreach or through appellant advocacy through FEMA appeals. If the program is properly structured, externs support the capacity of a legal aid office and train as future advocates to understand disaster outreach. Externs learn to adapt to address immediate priorities in the field and to understand how systems of justice continue to function under the duress of disaster. ${ }^{186}$

The learning objectives for a disaster response externship may include: understanding FEMA's role, comprehending the criteria for specific disaster benefits, engaging students in interviewing skills and direct intake, and more broadly understanding how lawyers serve as leaders to advocate and rebuild communities. In public service placements or judicial placements, externs are able to study the procedural and bureaucratic processes and learn about fair compliance with laws and regulations to improve disaster response and recovery efforts. For judicial externs, the learning goals may include analysis of the court's role and responsibility during a disaster to ensure that constitutional procedural timelines and process continue even under duress. ${ }^{187}$

Externship opportunities after disaster are ripe to engage students in learning through experience and to see themselves as leaders in the

184. Brandon L. Garrett \& Tania Tetlow, Criminal Justice Collapse: The Constitution After Hurricane Katrina, 56 DUKE. L. REV. 127 (2006); see also Mitchell F. CRusto, Involuntary Heroes: HurRicane Katrina's ImpaCT ON CIVIL LIBERTIES (Carolina Academic Press 2015).

185. See Training, FEMA, https://www.fema.gov/training [https://perma.cc /HWE9-CV6Z] (last updated Sept. 18, 2019); Complimentary Disaster Relief Courses for Attorneys Nationwide, LAwLINE, http://www.prweb.com/releases /2017/09/prweb14648139.htm [https://perma.cc/YA64-DTNK] (last visited Nov. 11, 2019).

186. Committee on Disaster Response and Preparedness, A.B.A., https:// www.americanbar.org/groups/committees/disaster/ [https://perma.cc/ASB8-WZ DR] (last visited Oct. 16, 2019).

187. Garrett \& Tetlow, supra note 184. 
community. Professors overseeing such experiences must quickly construct a curricular response to meet the needs for both students and field offices. Admittedly, oftentimes, law school curricula are not as nimble to construct a quick response, but this time of expanding experiential education calls for more action in the externship context to engage students with relevant experiences to prepare for the future.

\section{Post-Graduate Opportunities}

Law schools and each state's bar may improve access to justice after a disaster by creating post-graduate opportunities that help train new attorneys to be of service to disaster-stricken communities. Law schools that have post-graduate fellowships may consider devoting one to disaster relief, similar to the Reginald Heber Smith Community Lawyer Fellowship Program where new lawyers were placed at local legal services programs. ${ }^{188}$ The federal government established the "Reggie" Program in 1967 to train new lawyers in poverty law to help address local legal needs. Law schools may consider partnering with legal aid providers to request state and federal funds to support a cadre of disaster-relief lawyers who can be available to assist in disaster response wherever they occur.

Another vehicle for addressing the great legal needs post-disaster are law firm incubator programs. These programs can be vehicles for both pro bono and reduced rate services. Incubator programs allow private attorneys to provide basic consultations to advise clients of their rights and responsibilities but may also be willing to take on a case for a small fee that would not otherwise be serviced on a pro bono basis. Development of nominal or low fee models can supplement free legal services for those individuals who may not qualify for free legal services. There is a significant segment of the population of people impacted by disasters that would much prefer to pay something to get help than to wait to find free legal services. Lawyers who are building their own law practices should consider providing post-disaster legal services on a sliding scale fee.

\section{CONCLUSION}

In older times, an alarm would raise a fire brigade of neighbors storming out of their shops, offices, farms, and trades to assist each other with bucket

188. Katharina Hering, 50 Years Ago, the First Class of Reggies Completed Their Training at the University of Pennsylvania, GEO. L. LIBR. (Aug. 18, 2017), https://blogs.commons.georgetown.edu/righton/2017/08/18/50-years-ago-the-firstclass-of-reggies-completed-their-training-at-the-university-of-pennsylvania/ [https: //perma.cc/8KAL-WS3U]. 
lines, pumps, and evacuation. They would drop their work and rush to the rescue of a neighbor in danger because that danger affected them all. In this Article, we attempt to equip law schools, legal clinics, and law students with the ability to rise to the need when required in their communities. The storms, fires, blizzards, earthquakes, tsunamis, tornadoes, and floods will come, inevitably and inexorably, and lawyers can stand in the gap when our neighbors raise the alarm.

Surviving and recovering from natural disasters can be a scavenger hunt for resources and support. The needs are physical, economic, medical, psychological, emotional, financial, material, and spiritual. The law, legal system, government, and public policy affect all of these essential components of individual and community life. People need shelter, food, housing, insurance, safety, medical care, and access to short- and long-term assistance to rebuild and restore lives, communities, and businesses.

Lawyers are necessary to all of these steps and can be critical for clients trying to navigate a thicket of programs and policies who are in trauma and trying to survive. There are never enough pro bono and low bono lawyers, and persistent justice gaps only widen for vulnerable communities in a disaster. Law schools and legal clinics can leverage their public interest missions and talented law students to meet dual goals: helping communities recover and training young lawyers for effective practice.

Natural disasters do not arrive on a schedule, and they do not occur in predetermined places. To assure that every place is fully prepared at any given moment is not realistic or sustainable. To ensure that resources can deploy where and when people need them requires an on-call army of workers and the logistics to mobilize them. In the gaps stand the volunteer lawyers and public interest firms who rise to serve their own communities and neighbors, who lift themselves and their places from disaster. Law schools and legal clinics can and should join them with wise, responsive, and bold work for clients in urgent need. 